\title{
LEVEL II SCOUR ANALYSIS FOR BRIDGE 15 (GRNVTH00230015) on TOWN HIGHWAY 23, crossing the THIRD BRANCH of the WHITE RIVER, GRANVILLE, VERMONT
}

U.S. Geological Survey Open-File Report 96-564

Prepared in cooperation with

VERMONT AGENCY OF TRANSPORTATION and

FEDERAL HIGHWAY ADMINISTRATION 


\section{LEVEL II SCOUR ANALYSIS FOR BRIDGE 15 (GRNVTH00230015) on TOWN HIGHWAY 23, crossing the THIRD BRANCH of the WHITE RIVER, GRANVILLE, VERMONT}

By MICHAEL A. IVANOFF and SCOTT A. OLSON

U.S. Geological Survey

Open-File Report 96-564

Prepared in cooperation with

VERMONT AGENCY OF TRANSPORTATION and

FEDERAL HIGHWAY ADMINISTRATION 


\title{
U.S. DEPARTMENT OF THE INTERIOR BRUCE BABBITT, Secretary
}

\author{
U.S. GEOLOGICAL SURVEY \\ Gordon P. Eaton, Director
}

For additional information write to:

District Chief

U.S. Geological Survey 361 Commerce Way

Pembroke, NH 03275-3718
Copies of this report may be purchased from:

U.S. Geological Survey Earth Science Information Center Open-File Reports Section Box 25286, MS 517 Federal Center

Denver, CO 80225 


\section{CONTENTS}

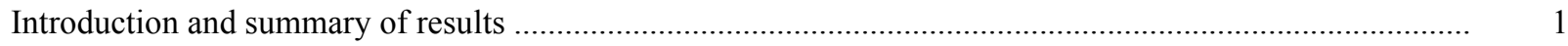

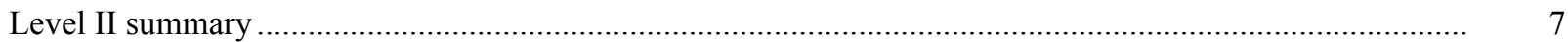

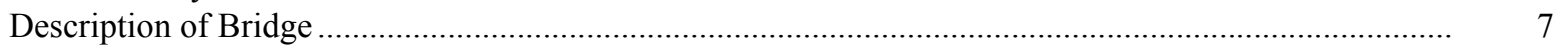

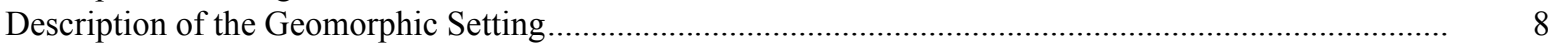

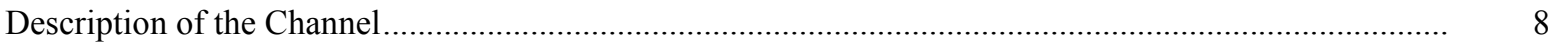

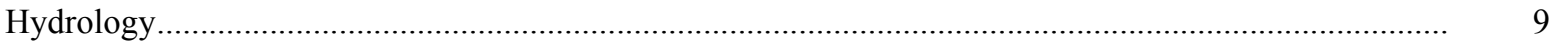

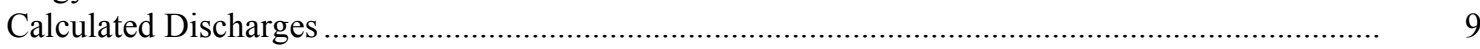

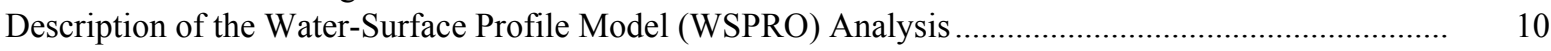

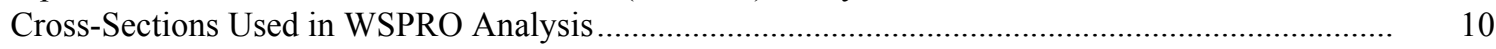

Data and Assumptions Used in WSPRO Model ...................................................................... 11

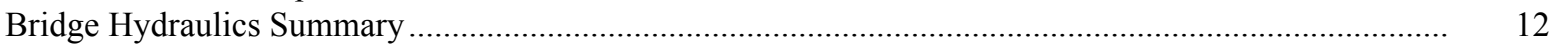

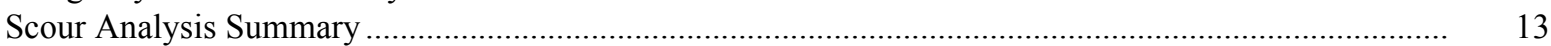

Special Conditions or Assumptions Made in Scour Analysis ...................................................... 13

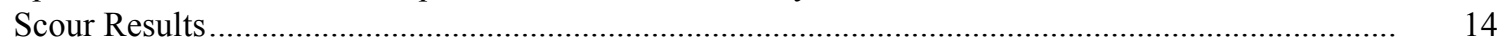

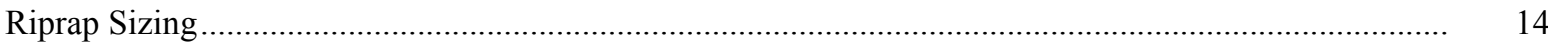

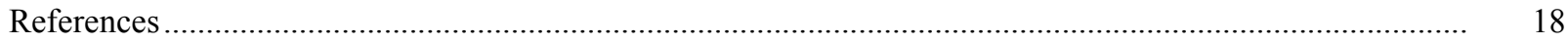

Appendixes:

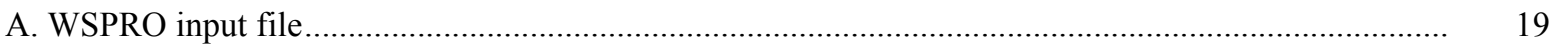

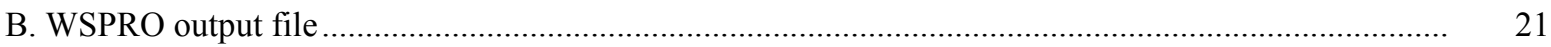

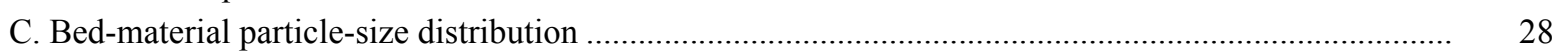

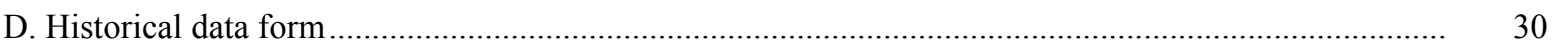

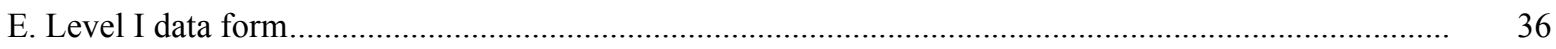

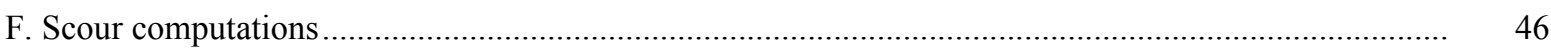

\section{FIGURES}

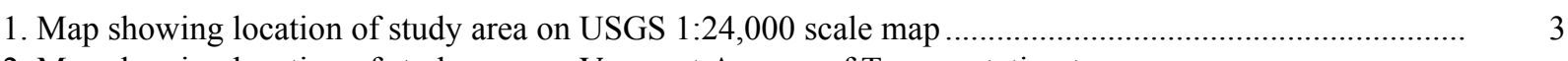

2. Map showing location of study area on Vermont Agency of Transportation town
highway map

3. Structure GRNVTH00230015 viewed from upstream (October 21, 1994) ............................................ 5

4. Downstream channel viewed from structure GRNVTH00230015 (October 21, 1994).......................... 5

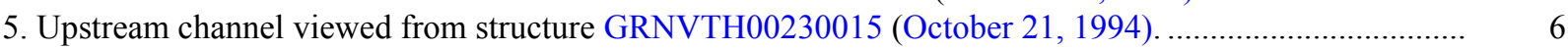

6. Structure GRNVTH00230015 viewed from downstream (October 21, 1994), ...................................... 6

7. Water-surface profiles for the 100- and 500-year discharges at structure

GRNVTH00230015 on Town Highway 23, crossing the Third Branch of the White River,

Granville, Vermont......

8. Scour elevations for the 100- and 500-year discharges at structure

GRNVTH00230015 on Town Highway 23, crossing the Third Branch of the White River,

Granville, Vermont.

\section{TABLES}

1. Remaining footing/pile depth at abutments for the 100-year discharge at structure

GRNVTH00230015 on Town Highway 23, crossing the Third Branch of the White River,

Granville, Vermont

2. Remaining footing/pile depth at abutments for the 500-year discharge at structure

GRNVTH00230015 on Town Highway 23, crossing the Third Branch of the White River,

Granville, Vermont

5




\begin{tabular}{|c|c|c|}
\hline Multiply & By & To obtain \\
\hline \multicolumn{3}{|c|}{ Length } \\
\hline inch (in.) & 25.4 & millimeter (mm) \\
\hline foot $(\mathrm{ft})$ & 0.3048 & $\operatorname{meter}(\mathrm{m})$ \\
\hline mile (mi) & 1.609 & kilometer (km) \\
\hline \multicolumn{3}{|c|}{ Slope } \\
\hline foot per mile ( $\mathrm{ft} / \mathrm{mi})$ & 0.1894 & meter per kilometer $(\mathrm{m} / \mathrm{km})$ \\
\hline \multicolumn{3}{|c|}{ Area } \\
\hline square mile $\left(\mathrm{mi}^{2}\right)$ & 2.590 & square kilometer $\left(\mathrm{km}^{2}\right)$ \\
\hline \multicolumn{3}{|c|}{ Volume } \\
\hline cubic foot $\left(\mathrm{ft}^{3}\right)$ & $\begin{array}{l}0.02832 \\
\text { Velocity and Flow }\end{array}$ & cubic meter $\left(\mathrm{m}^{3}\right)$ \\
\hline foot per second $(\mathrm{ft} / \mathrm{s})$ & 0.3048 & meter per second $(\mathrm{m} / \mathrm{s})$ \\
\hline cubic foot per second $\left(\mathrm{ft}^{3} / \mathrm{s}\right)$ & 0.02832 & cubic meter per second $\left(\mathrm{m}^{3} / \mathrm{s}\right)$ \\
\hline $\begin{array}{l}\text { cubic foot per second per } \\
\text { square mile } \\
{\left[\left(\mathrm{ft}^{3} / \mathrm{s}\right) / \mathrm{mi}^{2}\right]}\end{array}$ & 0.01093 & $\begin{array}{l}\text { cubic meter per } \\
\text { second per square } \\
\text { kilometer }\left[\left(\mathrm{m}^{3} / \mathrm{s}\right) / \mathrm{km}^{2}\right]\end{array}$ \\
\hline
\end{tabular}

OTHER ABBREVIATIONS

$\begin{array}{lrlr}\mathrm{BF} & \text { bank full } & \text { LWW } & \text { left wingwall } \\ \mathrm{cfs} & \text { cubic feet per second } & \text { MC } & \text { main channel } \\ \mathrm{D}_{50} & \text { median diameter of bed material } & \text { RAB } & \text { right abutment } \\ \mathrm{DS} & \text { downstream } & \text { RABUT } & \text { face of right abutment } \\ \mathrm{elev} & \text { elevation } & \text { RB } & \text { right bank } \\ \mathrm{f} / \mathrm{p} & \text { flood plain } & \text { ROB } & \text { right overbank } \\ \mathrm{ft} & \text { square feet } & \text { RWW } & \text { right wingwall } \\ \mathrm{ft} / \mathrm{ft} & \text { feet per foot } & \text { TH } & \text { town highway } \\ \mathrm{JCT} & \text { junction } & \text { UB } & \text { under bridge } \\ \mathrm{LAB} & \text { left abutment } & \text { US } & \text { upstream } \\ \mathrm{LABUT} & \text { face of left abutment } & \text { USGS } & \text { United States Geological Survey } \\ \text { LB } & \text { left bank } & \text { VTAOT Vermont Agency of Transportation } \\ \text { LOB } & \text { left overbank } & \text { WSPRO } & \text { water-surface profile model }\end{array}$

In this report, the words "right" and "left" refer to directions that would be reported by an observer facing downstream. Sea level: In this report, "sea level" refers to the National Geodetic Vertical Datum of 1929-- a geodetic datum derived from a general adjustment of the first-order level nets of the United States and Canada, formerly called Sea Level Datum of 1929.

In the appendices, the above abbreviations may be combined. For example, USLB would represent upstream left bank. 


\title{
LEVEL II SCOUR ANALYSIS FOR BRIDGE 15 (GRNVTH00230015) ON TOWN HIGHWAY 23, CROSSING THE THIRD BRANCH OF THE WHITE RIVER, GRANVILLE, VERMONT
}

\author{
By Michael A. Ivanoff and Scott A. Olson
}

\section{INTRODUCTION AND SUMMARY OF RESULTS}

This report provides the results of a detailed Level II analysis of scour potential at structure GRNVTH00230015 on town highway 23 crossing the Third Branch of the White River, Granville, Vermont (figures 1-8). A Level II study is a basic engineering analysis of the site, including a quantitative analysis of stream stability and scour (U.S. Department of Transportation, 1993). A Level I study is included in Appendix E of this report. A Level I study provides a qualitative geomorphic characterization of the study site. Information on the bridge, gleaned from Vermont Agency of Transportation (VTAOT) files, was compiled prior to conducting Level I and Level II analyses and can be found in Appendix D.

The site is in the Green Mountain physiographic province of central Vermont in the town of Granville. The 23.6- $\mathrm{mi}^{2}$ drainage area is in a predominantly rural and forested basin. In the vicinity of the study site, the banks have woody vegetation coverage except for the downstream banks, which are residential.

In the study area, the Third Branch of the White River has an incised, sinuous channel with a slope of approximately $0.0128 \mathrm{ft} / \mathrm{ft}$, an average channel top width of $42 \mathrm{ft}$ and an average channel depth of $4 \mathrm{ft}$. The predominant channel bed material is cobble $\left(\mathrm{D}_{50}\right.$ is $108 \mathrm{~mm}$ or $0.353 \mathrm{ft}$ ). The geomorphic assessment at the time of the Level I and Level II site visit on October 21, 1994, indicated that the reach was laterally unstable.

The town highway 23 crossing of the Third Branch of the White River is a 35-ft-long, onelane bridge consisting of one 31-foot steel beam span (Vermont Agency of Transportation, written communication, August 26, 1994). The bridge is supported by vertical, concrete abutments with wingwalls. The channel is skewed approximately 10 degrees to the opening while the opening-skew-to-roadway is 10 degrees.

The only scour protection measures in place at the site were type-1 stone fill (less than 12 inches diameter) along the upstream right bank, upstream right wingwall, and right abutment. Retaining walls are in place along the upstream left bank up to the upstream end of the upstream left wingwall and both downstream banks with the left bank wall extending from the downstream left wingwall. Additional details describing conditions at the site are included in the Level II Summary and Appendices D and E. 
Scour depths and rock rip-rap sizes were computed using the general guidelines described in Hydraulic Engineering Circular 18 (Richardson and others, 1995).

Total scour at a highway crossing is comprised of three components: 1) long-term streambed degradation; 2) contraction scour (due to accelerated flow caused by a reduction in flow area at a bridge) and; 3 ) local scour (caused by accelerated flow around piers and abutments). Total scour is the sum of the three components. Equations are available to compute scour depths for contraction and local scour and a summary of the results of these computations follows.

Contraction scour for all modelled flows ranged from 0 to $0.4 \mathrm{ft}$. The worst-case contraction scour occurred at the incipient overtopping discharge. Abutment scour ranged from 9.8 to $13.9 \mathrm{ft}$. The worst-case abutment scour occurred at the 100-year discharge. Additional information on scour depths and depths to armoring are included in the section titled "Scour Results". Scoured-streambed elevations, based on the calculated depths, are presented in tables 1 and 2. A cross-section of the scour computed at the bridge is presented in figure 8 . Scour depths were calculated assuming an infinite depth of erosive material and a homogeneous particle-size distribution.

It is generally accepted that the Froehlich equation (abutment scour) gives "excessively conservative estimates of scour depths" (Richardson and others, 1995, p. 47). Usually, computed scour depths are evaluated in combination with other information including (but not limited to) historical performance during flood events, the geomorphic stability assessment, existing scour protection measures, and the results of the hydraulic analyses. Therefore, scour depths adopted by VTAOT may differ from the computed values documented herein. 


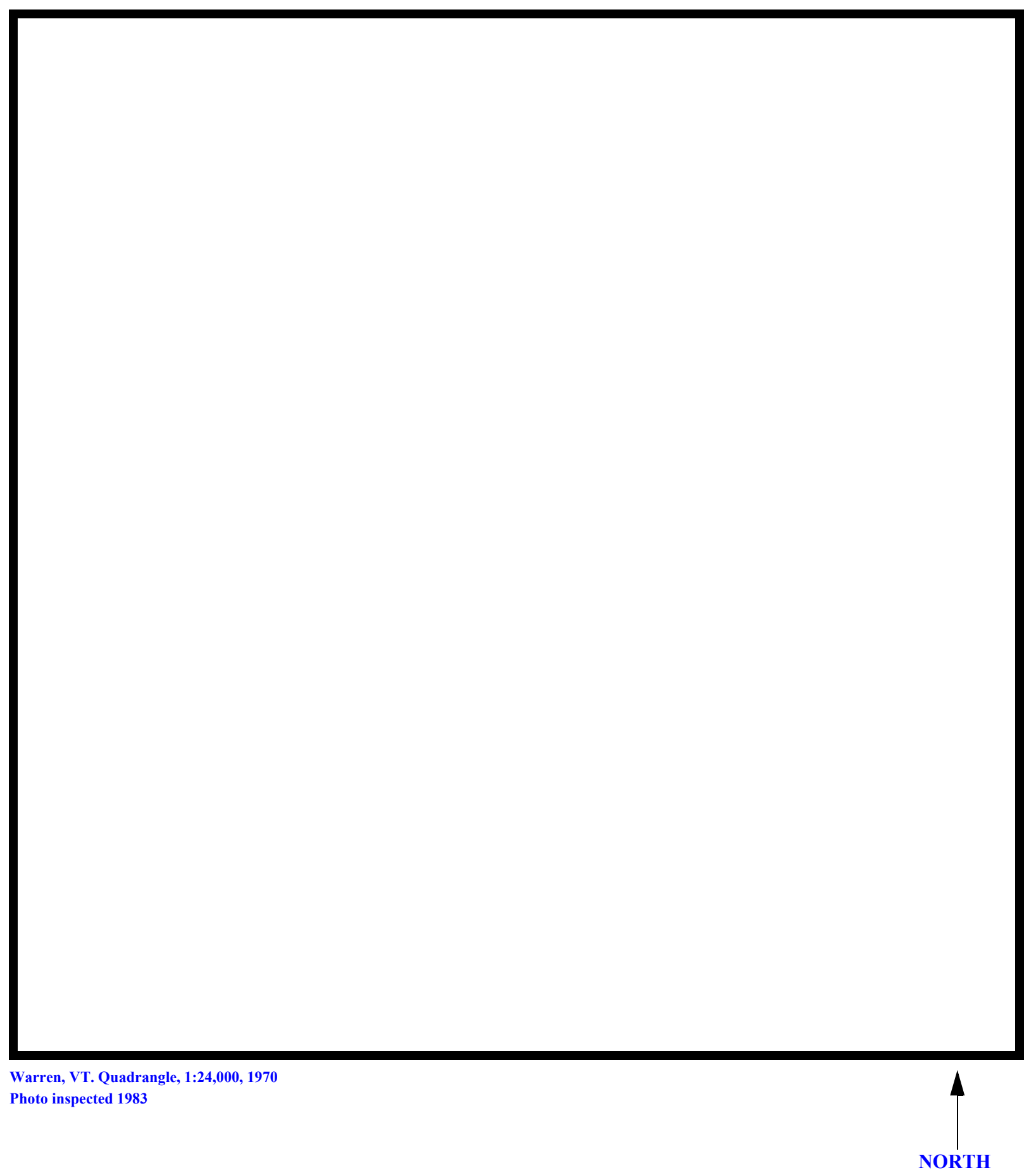

Figure 1. Location of study area on USGS 1:24,000 scale map. 
Figure 2. Location of study area on Vermont Agency of Transportation town highway map. 

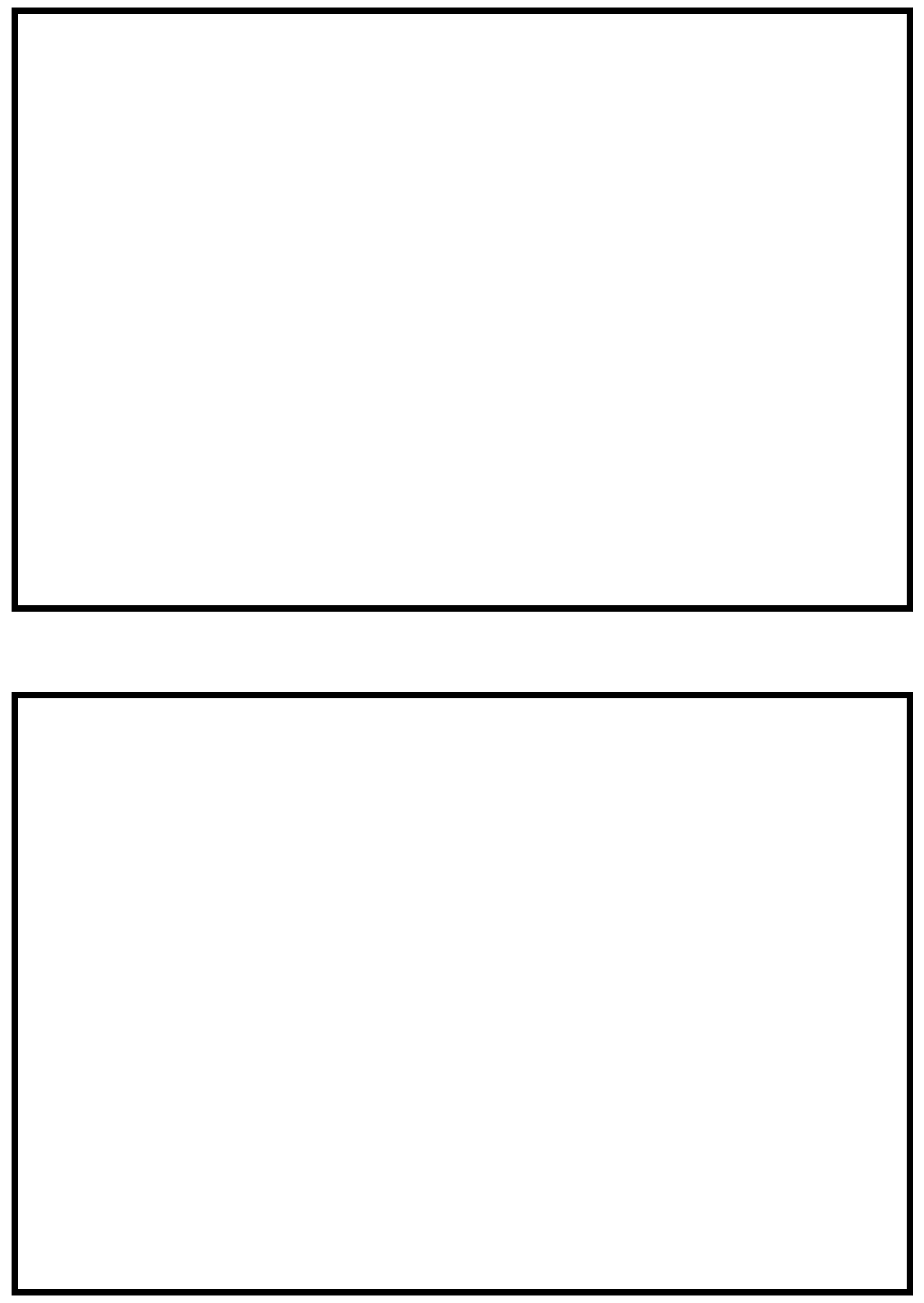

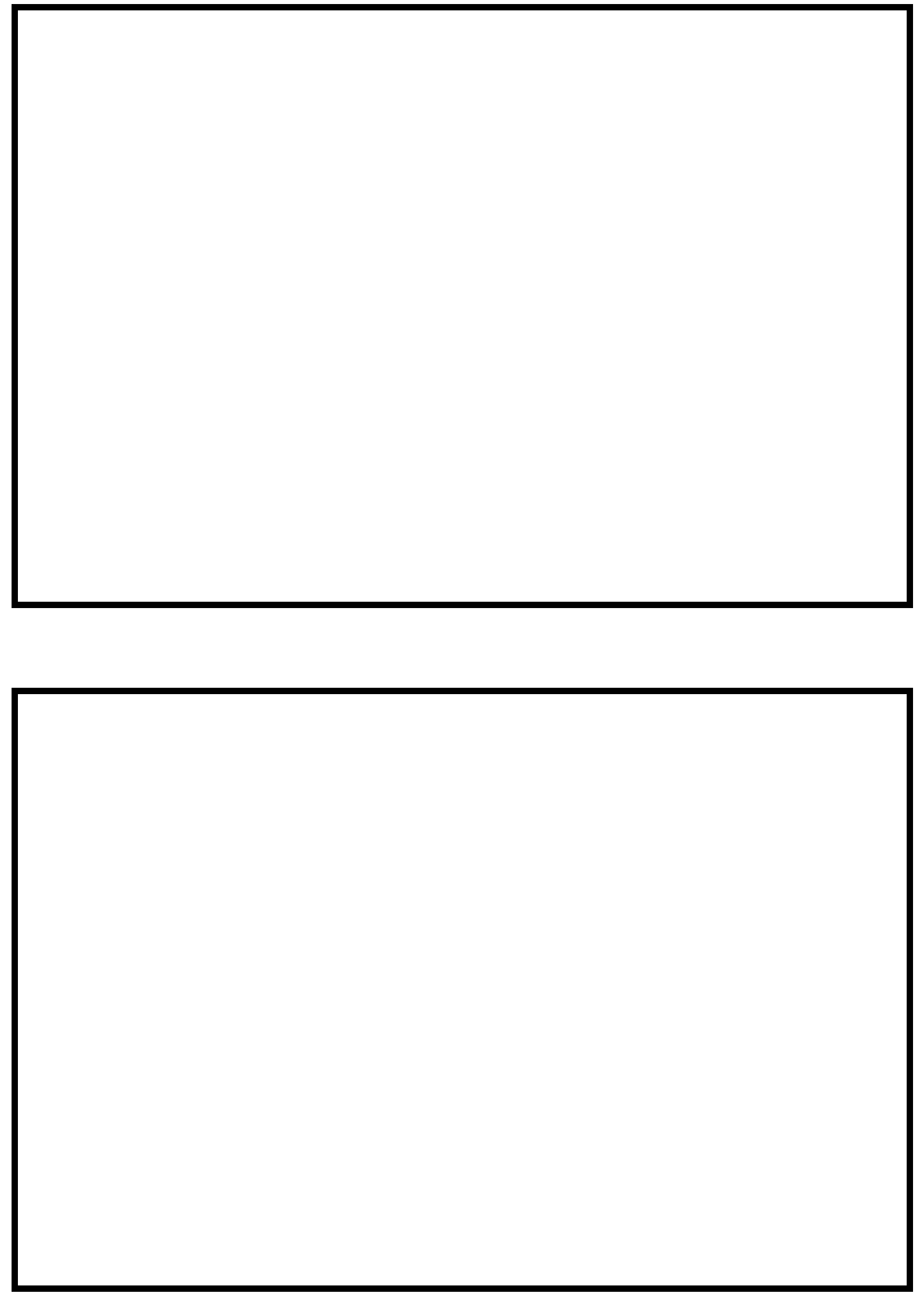


\section{LEVEL II SUMMARY}

\begin{tabular}{llllll} 
Structure Number & GRNVTH00230015 & Stream & \multicolumn{2}{c}{ Third Branch of the White River } \\
& Road & TH 23 & District & 04 \\
County & Addison & Roan &
\end{tabular}

\section{Description of Bridge}

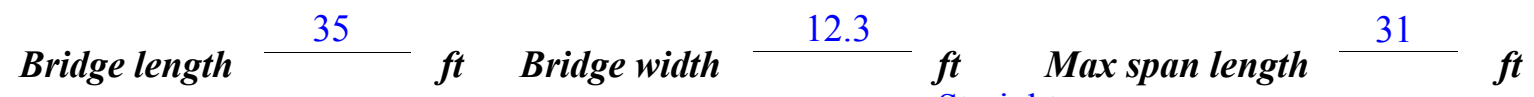
Alignment of bridge to road (on curve or straight) Abutment type Vertical

Stone fill on abutment?

\section{Embankment type} Straight

\section{Nacraintin... af ata... a fill}

$$
\text { Yes }
$$

Dato af incnortion Sloping

\section{Type-1, along US right bank, US right wingwall, and right abutment.}

Retaining walls are along US left bank up to the US end of the US left wingwall and both DS banks with the left bank wall extending from the DS left wingwall.

Abutments and wingwalls are concrete.

$\ldots \ldots \ldots$

\section{Yes}

Is bridge skewed to flood flow according to Yes 'survey? Angle

There is a mild channel bend in the upstream reach.

Debris accumulation on bridge at time of Level I or Level II site visit:

\begin{tabular}{|c|c|c|}
\hline $\begin{array}{c}\text { Date at insnortion } \\
10 / 21 / 94\end{array}$ & $\begin{array}{l}\text { Percent of almanol } \\
\text { blocked inortzontatly }\end{array}$ & $\begin{array}{l}\text { Percent of } 0 \\
\text { blocked verticatty }\end{array}$ \\
\hline & () & 0 \\
\hline
\end{tabular}

Level I

Moderate. There is some debris caught on a tree on the left bank

Level II

upstream. The upstream banks are unstable with trees lining the channel.

Potential for debris

A side bar begins under the bridge extending downstream along the left abutment and left bank Doscriho anv fonturos noar ar at tho hridoo that mav affort flow, (includo ahsorvation dato) $10 / 21 / 94$. 


\section{Description of the Geomorphic Setting}

General topography The channel is located within a moderate relief valley with a narrow flood plain and steep valley walls on both sides.

Geomorphic conditions at bridge site: downstream (DS), upstream (US)

Date of inspection $\quad 10 / 21 / 94$

DS left: $\quad$ Gradually sloped channel bank to a narrow gradually sloped flood plain

DS right: $\quad$ Steep channel bank to a narrow gradually sloped flood plain

US left: $\quad$ Moderately sloped channel bank to a narrow gradually sloped flood plain

US right: $\quad$ Moderately sloped bank

\section{Description of the Channel}

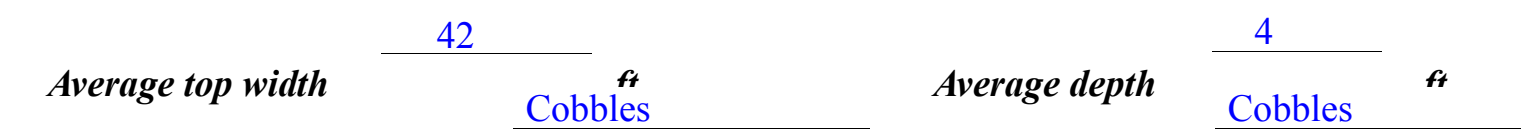

Predominant bed material

Bank material Sinuous and wider at

bends with irregular point and lateral bars and semi-alluvial channël boundaries.

$10 / 21 / 94$

Vegetative co 1 Trees and brush

DS left: $\quad$ Brush and multiple homes on the bank

DS right: $\quad$ Trees and brush on the bank with short grass on the flood plain

US left: $\quad$ Trees and brush on the bank with railroad on bank

US right: $\quad$ No

Do banks appear stable? The banks in the immediate vicinity of the bridge, are protected by Walls. A cut bank was noted along the upstream left bank 10/21/94.
date of observattom.

None -- 10/21/94

Describe any obstructions in channel and date of observation. 


\section{Hydrology}

Drainage area $\quad 23.6 \quad \boldsymbol{m i}^{2}$

Percentage of drainage area in physiographic provinces: (approximate)

Physiographic province

Green Mountain
Percent of drainage area

100

Is drainage area considered rural or urban? Rural _ Describe any significant

urbanization: There are a couple houses on the downstream right overbank area

Is there a USGS gage on the stream of interest?

No

\section{USGS gage description}

USGS gage number

Gage drainage area $\mathrm{mi}^{2}$

No

Is there a lake/p .

$, \ldots, \ldots, \ldots, \cdots, \cdots$

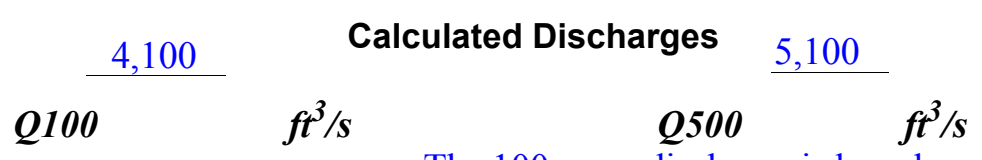

The 100- year discharge is based on values from the

VTAOT database and those computed by use of several empirical methods (Potter, 1957a\&b;

Johnson and Tasker, 1974; Benson, 1962; FHWA, 1983; Talbot, 1887; Richardson and others,

1993). The 500-year discharge is based on an extrapolation of the empirical relationship flood frequency curves and that of the VTAOT database values (VTAOT, written communication, May 4, 1995). VTAOT database values were from another site downstream. 


\section{Description of the Water-Surface Profile Model (WSPRO) Analysis}

Datum for WSPRO analysis (USGS survey, sea level, VTAOT plans)

USGS survey

Datum tie between USGS survey and VTAOT plans

None

Description of reference marks used to determine USGS datum. $\quad$ RM1 is the center of a

chiseled square on top of the DS end of the right abutment (elev. $496.86 \mathrm{ft}$, arbitrary survey

datum). RM2 is a chiseled square on top of the US end of the right abutment (elev. 496.75ft,

arbitrary survey datum).

\section{Cross-Sections Used in WSPRO Analysis}

\begin{tabular}{cccl}
\hline${ }^{1}$ Cross-section & $\begin{array}{c}\text { Section } \\
\text { Reference } \\
\text { Distance } \\
\text { (SRD) infeet }\end{array}$ & $\begin{array}{c}{ }^{2} \text { Cross-section } \\
\text { development }\end{array}$ & \multicolumn{1}{c}{ Comments } \\
EXITX & -29 & 1 & $\begin{array}{l}\text { Exit section } \\
\text { Downstream Full-valley } \\
\text { section (Templated from } \\
\text { FULLV }\end{array}$ \\
BRIDG & 0 & 2 & $\begin{array}{l}\text { EXITX) } \\
\text { Bridge section }\end{array}$ \\
RDWAY & 0 & 1 & Road Grade section \\
APPRO & 51 & 1 & Approach section \\
\hline
\end{tabular}

${ }^{1}$ For location of cross-sections see plan-view sketch included with Level I field form, Appendix E. For more detail on how cross-sections were developed see WSPRO input file. 


\section{Data and Assumptions Used in WSPRO Model}

Hydraulic analyses of the reach were done by use of the Federal Highway Administration's WSPRO step-backwater computer program (Shearman and others, 1986, and Shearman, 1990). The analyses reported herein reflect conditions existing at the site at the time of the study. Furthermore, in the development of the model it was necessary to assume no accumulation of debris or ice at the site. Results of the hydraulic model are presented in the Bridge Hydraulic Summary, Appendix B, and figure 7.

Channel roughness factors (Manning's " $n$ ") used in the hydraulic model were estimated using field inspections at each cross section following the general guidelines described by Arcement, Jr. and Schneider (1989). Final adjustments to the values were made during the modelling of the reach. Channel " $\mathrm{n}$ " values for the reach ranged from 0.035 to 0.046 , and overbank " $\mathrm{n}$ " values ranged from 0.035 to 0.065 .

Normal depth at the exit section (EXITX) was assumed as the starting water surface. This depth was computed by use of the slope-conveyance method outlined in the user's manual for WSPRO (Shearman, 1990). The slope used was $0.0128 \mathrm{ft} / \mathrm{ft}$ which was measured from channel thalweg points surveyed at and downstream of the exit section.

The approach section was surveyed one bridge length upstream of the upstream face as recommended by Shearman and others (1986). This approach also provides a consistent method for determining scour variables.

For the 500-year discharge, WSPRO assumes a critical depth at the exit section. A supercritical model was developed for the discharge. Analyzing both the supercritical and subcritical profiles for the discharge, it can be determined that the water surface profile does pass through critical depth at the exit. Thus, the assumption of critical depth at the exit is a satifactory solution. 


\section{Bridge Hydraulics Summary}

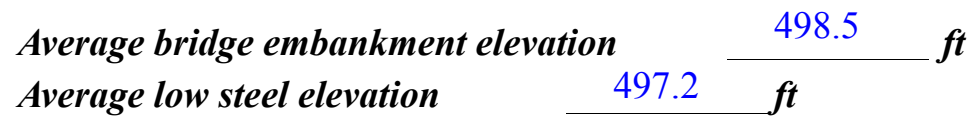

$$
\text { 100-year discharge } \quad 4,100 \quad \mathrm{ft}^{3} / \mathrm{s}
$$

Water-surface elevation in bridge opening $\quad 497.5 \quad f t$

Road overtopping? ___ Yes Discharge over road _ 1756 , s

\begin{tabular}{llcc} 
Area of flow in bridge opening & $236 \quad \boldsymbol{f t}^{2}$ & \\
\cline { 2 - 3 } Average velocity in bridge opening & 9.8 & $\boldsymbol{f t} / \mathrm{s}$
\end{tabular}

$\begin{array}{llll}\text { Maximum WSPRO tube velocity at bridge } & 11.6 \mathrm{ft} / \mathrm{s}\end{array}$

Water-surface elevation at Approach section with bridge 500.6

Water-surface elevation at Approach section without bridge $\quad \overline{499.7}$

Amount of backwater caused by bridge $\quad 0.9$ it

500-year discharge $\quad 5,100 \quad \mathrm{ft}^{3} / \mathrm{s}$

Water-surface elevation in bridge opening $\quad 497.5 \mathrm{ft}$

Road overtopping? ___ Yes Discharge over road _ $2960, \mathrm{~J} / \mathrm{s}$

Area of flow in bridge opening $\quad 236 \quad \mathrm{ft}^{2}$

Average velocity in bridge opening $\quad 9.1 \mathrm{ft} / \mathrm{s}$

Maximum WSPRO tube velocity at bridge 10.8 , s

Water-surface elevation at Approach section with bridge 501.4

Water-surface elevation at Approach section without bridge $\quad 500.6$

Amount of backwater caused by bridge 0.8 .

Incipient overtopping discharge $\quad 2,220 \mathrm{ft}^{3} / \mathrm{s}$

Water-surface elevation in bridge opening $495.0 \quad t$

Area of flow in bridge opening $\quad 176 \quad \mathrm{ft}^{2}$

Average velocity in bridge opening $\quad 12.6 \quad \mathrm{ft} / \mathrm{s}$

Maximum WSPRO tube velocity at bridge $\quad 15.5 \mathrm{ft} / \mathrm{s}$

Water-surface elevation at Approach section with bridge

Water-surface elevation at Approach section without bridge

497.3

Amount of backwater caused by bridge $\quad 0.4$ it 


\section{Scour Analysis Summary}

\section{Special Conditions or Assumptions Made in Scour Analysis}

Scour depths were computed using the general guidelines described in Hydraulic Engineering Circular 18 (Richardson and others, 1995). Scour depths were calculated assuming an infinite depth of erosive material and a homogeneous particle-size distribution. The results of the scour analysis are presented in tables 1 and 2 and a graph of the scour depths is presented in figure 8 .

Contraction scour was computed by use of the Chang pressure-flow scour equation (Richarson and others, 1995, p. 145-146) for the 100-year and 500-year discharges. For these modelled discharges, there was orifice flow at the bridge. Contraction scour at bridges with orifice flow is best estimated by use of the Chang pressure-flow scour equation (oral communication, J. Sterling Jones, October 4, 1996). The results of Laursen's clear-water contraction scour equation (Richardson and others, 1995, p. 32, equation 20) were also computed for the 100-year and 500-year discharges and can be found in appendix F. Contraction scour was computed by use of the clear-water contraction scour equation (Richardson and others, 1995, p. 32, equation 20) for the incipient road-overflow discharge. For contraction scour computations using the Laursen's equation, the average depth in the contracted section (AREA/TOPWIDTH) is subtracted from the depth of flow computed by the scour equation (Y2) to determine the actual amount of scour. In this case, the incipient road-overflow model resulted in the worst case contraction scour with a scour depth of 0.4 $\mathrm{ft}$. The incipient road-overflow model resulted in the worst case total scour with depths of 10.7 and 13.4, respectively for the left and right abutment. The results of the streambed armoring computations suggest that the depth of contraction scour will not be limited by armoring.

Abutment scour was computed by use of the Froehlich equation (Richardson and others, 1995, p. 48, equation 28). Variables for the Froehlich equation include the Froude number of the flow approaching the embankments, the length of the embankment blocking flow, and the depth of flow approaching the embankment less any roadway overtopping. 


\section{Scour Results}

$$
\text { 100-yr discharge 500-yr discharge }
$$

(Scour depths in feet)

Main channel

Live-bed scour

Clear-water scour

Depth to armoring

Left overbank

Right overbank

Local scour:

Abutment scour

Left abutment

Right abutment

Pier scour

Pier 1

Pier 2

Pier 3
9.8

13.9-
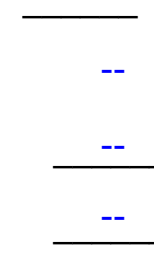

10.4

13.6-
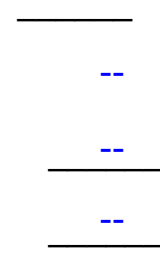

$+2$
Incipient discharge 


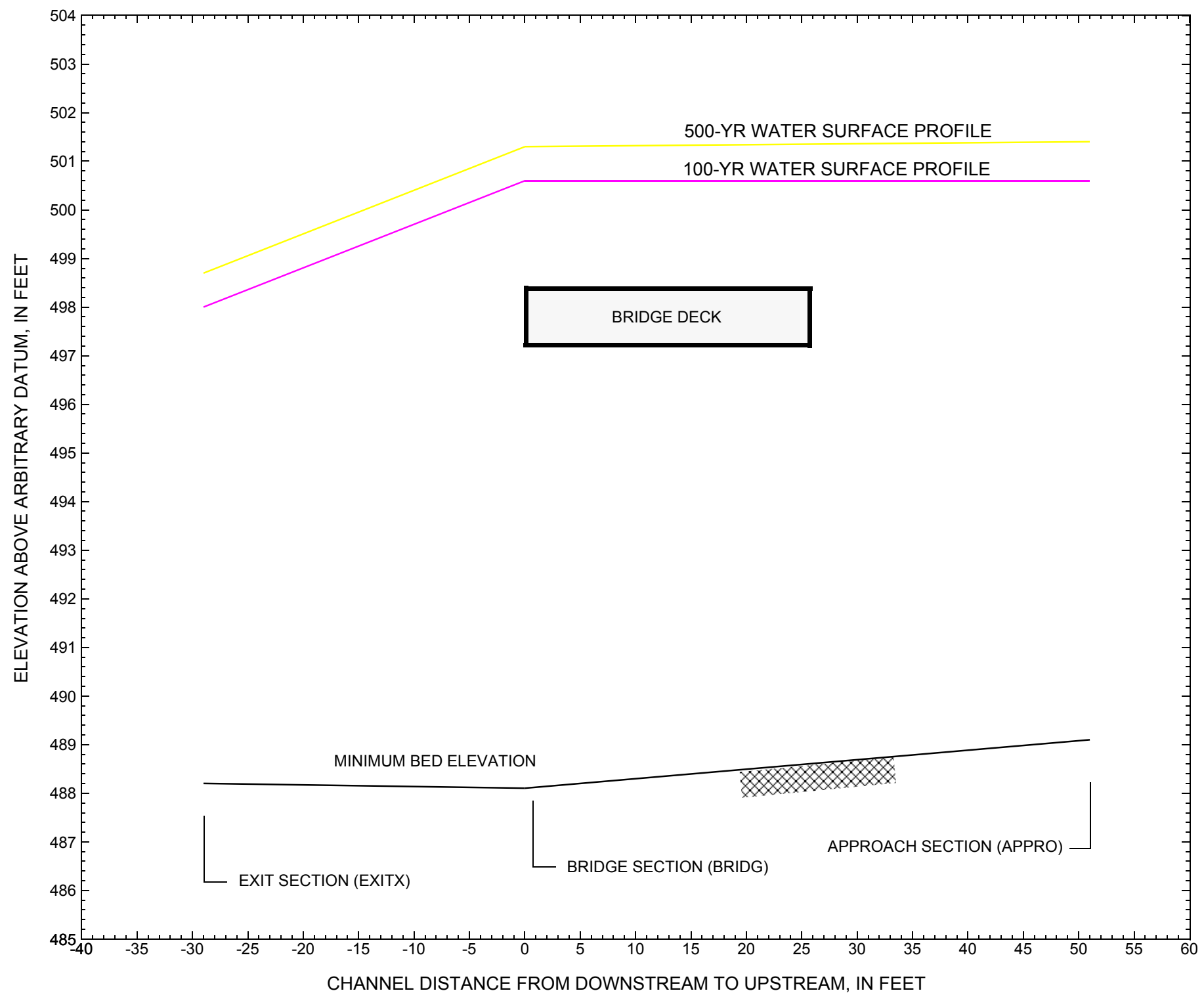

Figure 7. Water-surface profiles for the 100- and 500-yr discharges at structure GRNVTH00230015 on town highway 23, crossing the Third Branch of the White River, Granville, Vermont. 


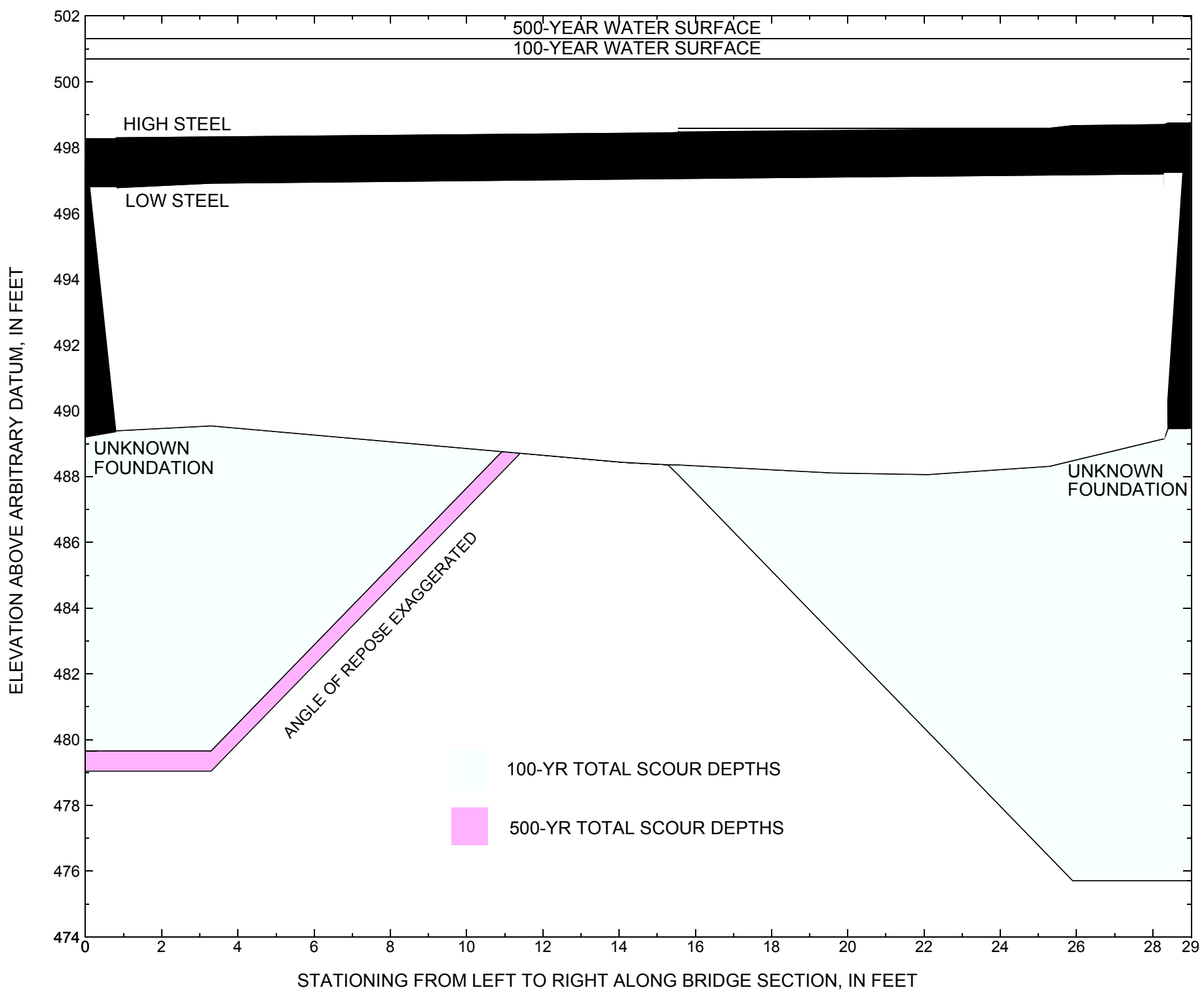

Figure 8. Scour elevations for the 100-yr and 500-yr discharges at structure GRNVTH00230015 on town highway 23, crossing the Third Branch of the White River, Granville, Vermont. 


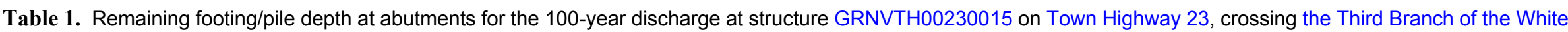
River, Granville, Vermont.

[VTAOT, Vermont Agency of Transportation; --,no data]

\begin{tabular}{|c|c|c|c|c|c|c|c|c|c|c|c|}
\hline Description & Station $^{1}$ & $\begin{array}{l}\text { VTAOT } \\
\text { minimum } \\
\text { low-chord } \\
\text { elevation } \\
\text { (feet) }\end{array}$ & $\begin{array}{l}\text { Surveyed } \\
\text { minimum } \\
\text { low-chord } \\
\text { elevation } \\
\text { (feet) }\end{array}$ & $\begin{array}{l}\text { Bottom of } \\
\text { footing } \\
\text { elevation } \\
\text { (feet) }\end{array}$ & $\begin{array}{c}\text { Channel } \\
\text { elevation at } \\
\text { abutment/ } \\
\text { pier }^{2} \\
\text { (feet) }\end{array}$ & $\begin{array}{l}\text { Contraction } \\
\text { scour depth } \\
\text { (feet) }\end{array}$ & $\begin{array}{l}\text { Abutment } \\
\text { scour } \\
\text { depth } \\
\text { (feet) }\end{array}$ & $\begin{array}{l}\text { Pier } \\
\text { scour } \\
\text { depth } \\
\text { (feet) }\end{array}$ & $\begin{array}{l}\text { Depth of } \\
\text { total scour } \\
\text { (feet) }\end{array}$ & $\begin{array}{l}\text { Elevation of } \\
\text { scour }^{2} \\
\text { (feet) }\end{array}$ & $\begin{array}{c}\text { Remaining } \\
\text { footing/pile } \\
\text { depth } \\
\text { (feet) }\end{array}$ \\
\hline \multicolumn{12}{|c|}{100 -yr. discharge is 4,100 cubic-feet per second } \\
\hline Left abutment & 0.0 & -- & 496.8 & -- & 489.4 & 0.0 & 9.8 & -- & 9.8 & 479.6 & -- \\
\hline Right abutment & 29.0 & -- & 497.5 & -- & 489.5 & 0.0 & 13.9 & -- & 13.9 & 475.6 & -- \\
\hline
\end{tabular}

1. Measured along the face of the most constricting side of the bridge.

2. Arbitrary datum for this study.

Table 2. Remaining footing/pile depth at abutments for the 500-year discharge at structure GRNVTH00230015 on Town Highway 23, crossing the Third Branch of the White River, Granville, Vermont.

[VTAOT, Vermont Agency of Transportation; --, no data]

\begin{tabular}{|c|c|c|c|c|c|c|c|c|c|c|c|}
\hline Description & Station $^{1}$ & $\begin{array}{l}\text { VTAOT } \\
\text { minimum } \\
\text { low-chord } \\
\text { elevation } \\
\text { (feet) }\end{array}$ & $\begin{array}{l}\text { Surveyed } \\
\text { minimum } \\
\text { low-chord } \\
\text { elevation } \\
\text { (feet) }\end{array}$ & $\begin{array}{l}\text { Bottom of } \\
\text { footing } \\
\text { elevation } \\
\text { (feet) }\end{array}$ & $\begin{array}{c}\text { Channel } \\
\text { elevation at } \\
\text { abutment/ } \\
\text { pier }^{2} \\
\text { (feet) }\end{array}$ & $\begin{array}{l}\text { Contraction } \\
\text { scour depth } \\
\text { (feet) }\end{array}$ & $\begin{array}{l}\text { Abutment } \\
\text { scour } \\
\text { depth } \\
\text { (feet) }\end{array}$ & $\begin{array}{l}\text { Pier } \\
\text { scour } \\
\text { depth } \\
\text { (feet) }\end{array}$ & $\begin{array}{l}\text { Depth of } \\
\text { total scour } \\
\text { (feet) }\end{array}$ & $\begin{array}{c}\text { Elevation of } \\
\text { scour }^{2} \\
\text { (feet) }\end{array}$ & $\begin{array}{c}\text { Remaining } \\
\text { footing/pile } \\
\text { depth } \\
\text { (feet) }\end{array}$ \\
\hline \multicolumn{12}{|c|}{500 -yr. discharge is 5,100 cubic-feet per second } \\
\hline Left abutment & 0.0 & -- & 496.8 & -- & 489.4 & 0.0 & 10.4 & -- & 10.4 & 479.0 & -- \\
\hline Right abutment & 29.0 & -- & 497.5 & -- & 489.5 & 0.0 & 13.6 & -- & 13.6 & 475.9 & -- \\
\hline
\end{tabular}

1. Measured along the face of the most constricting side of the bridge.

2. Arbitrary datum for this study. 


\section{SELECTED REFERENCES}

Arcement, G.J., Jr., and Schneider, V.R., 1989, Guide for selecting Manning's roughness coefficients for natural channels and flood plains: U.S. Geological Survey Water-Supply Paper 2339, 38 p.

Barnes, H.H., Jr., 1967, Roughness characteristics of natural channels: U.S. Geological Survey Water-Supply Paper 1849, 213 p.

Benson, M.A., 1962, Factors influencing the occurrence of floods in a humid region of diverse terrain: U.S. Geological Survey Water-Supply Paper 1580-B, 64 p.

Brown, S.A. and Clyde, E.S., 1989, Design of riprap revetment: Federal Highway Administration Hydraulic Engineering Circular No. 11, Publication FHWA-IP-89-016, 156 p.

Federal Highway Administration, 1983, Runoff estimates for small watersheds and development of sound design: Federal Highway Administration Report FHWA-RD-77-158

Froehlich, D.C., 1989, Local scour at bridge abutments in Ports, M.A., ed., Hydraulic Engineering--Proceedings of the 1989 National Conference on Hydraulic Engineering: New York, American Society of Civil Engineers, p. 13-18.

Hayes, D.C.,1993, Site selection and collection of bridge-scour data in Delaware, Maryland, and Virginia: U.S. Geological Survey Water-Resources Investigation Report 93-4017, 23 p.

Johnson, C.G. and Tasker, G.D.,1974, Progress report on flood magnitude and frequency of Vermont streams: U.S. Geological Survey Open-File Report 74-130, 37 p.

Lagasse, P.F., Schall, J.D., Johnson, F., Richardson, E.V., Chang, F., 1995, Stream Stability at Highway Structures: Federal Highway Administration Hydraulic Engineering Circular No. 20, Publication FHWA-IP-90-014, 144 p.

Laursen, E.M., 1960, Scour at bridge crossings: Journal of the Hydraulics Division, American Society of Civil Engineers, v. 86, no. HY2, p. 39-53.

Potter, W. D., 1957a, Peak rates of runoff in the Adirondack, White Mountains, and Maine woods area, Bureau of Public Roads

Potter, W. D., 1957b, Peak rates of runoff in the New England Hill and Lowland area, Bureau of Public Roads

Richardson, E.V. and Davis, S.R., 1995, Evaluating scour at bridges: Federal Highway Administration Hydraulic Engineering Circular No. 18, Publication FHWA-IP-90-017, 204 p.

Richardson, E.V., Simons, D.B., and Julien, P.Y., 1990, Highways in the river environment: Federal Highway Administration Publication FHWA-HI-90-016.

Ritter, D.F., 1984, Process Geomorphology: W.C. Brown Co., Debuque, Iowa, 603 p.

Shearman, J.O., 1990, User's manual for WSPRO--a computer model for water surface profile computations: Federal Highway Administration Publication FHWA-IP-89-027, 187 p.

Shearman, J.O., Kirby, W.H., Schneider, V.R., and Flippo, H.N., 1986, Bridge waterways analysis model; research report: Federal Highway Administration Publication FHWA-RD-86-108, 112 .

Talbot, A.N., 1887, The determination of water-way for bridges and culverts.

U.S. Department of Transportation, 1993, Stream stability and scour at highway bridges, Participant Workbook: Federal Highway Administration Publication FHWA HI-91-011.

U.S. Geological Survey, 1970, Warren, Vermont 7.5 Minute Series quadrangle map: U.S. Geological Survey Topographic Maps, Photoinspected 1983, Scale 1:24,000. 


\section{APPENDIX A: \\ WSPRO INPUT FILE}




\section{WSPRO INPUT FILE}

GR

GR

GR

GR

GR

GR

N

SA

X

$\mathrm{BR}$

GR

GR

GR

*

CD

$\mathrm{N}$

*

$\mathrm{XR}$

GR

GR

GR

*

AS

GR

GR

GR

GR

GR

GR

N

$\mathrm{SA}$

*

HP 1 BRIDG

HP 2 BRIDG

HP 2 RDWAY

HP 1 APPRO

HP 2 APPRO

*

HP 1 BRIDG

HP 2 BRIDG

HP 2 RDWAY

HP 1 APPRO

HP 2 APPRO
U.S. Geological Survey WSPRO Input File grnv015.wsp Hydraulic analysis for structure GRNVTH00230015 Date: 19-APR-96 Town Highway 23 Bridge Over the 3rd Branch White River, Granville MAI $4100.0 \quad 5100.0 \quad 2220.0$

$\begin{array}{lll}0.0128 & 0.0128 & 0.0128\end{array}$

$\begin{array}{lllllllllllllllllllll}6 & 29 & 30 & 552 & 553 & 551 & 5 & 16 & 17 & 13 & 3 & * & 15 & 14 & 23 & 21 & 11 & 12 & 4 & 7 & 3\end{array}$ $\operatorname{EXITX} \quad-29$

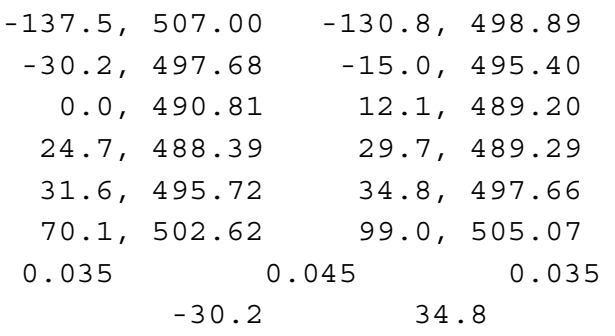




\section{APPENDIX B: \\ WSPRO OUTPUT FILE}




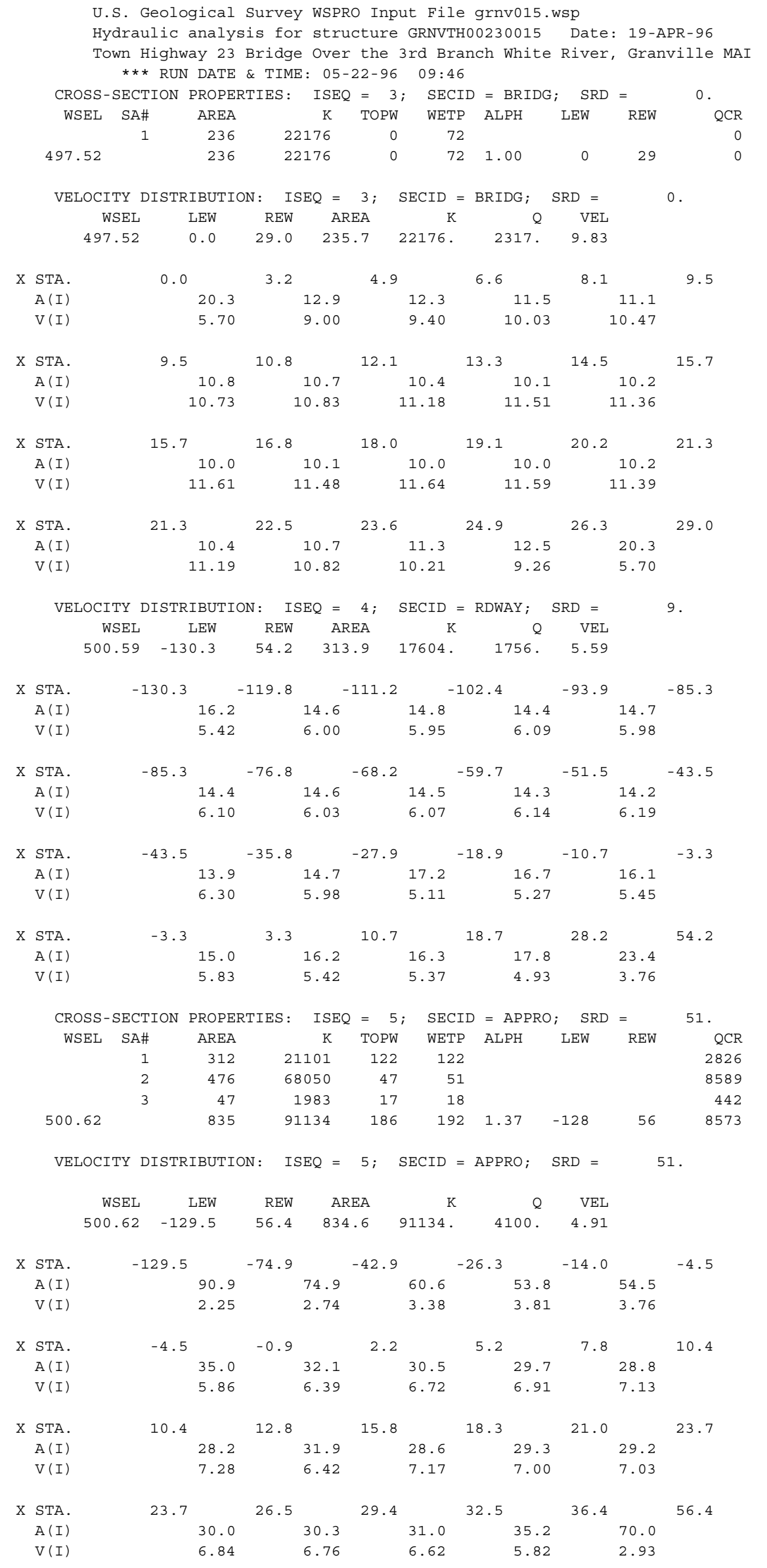


WSPRO OUTPUT FILE (continued)

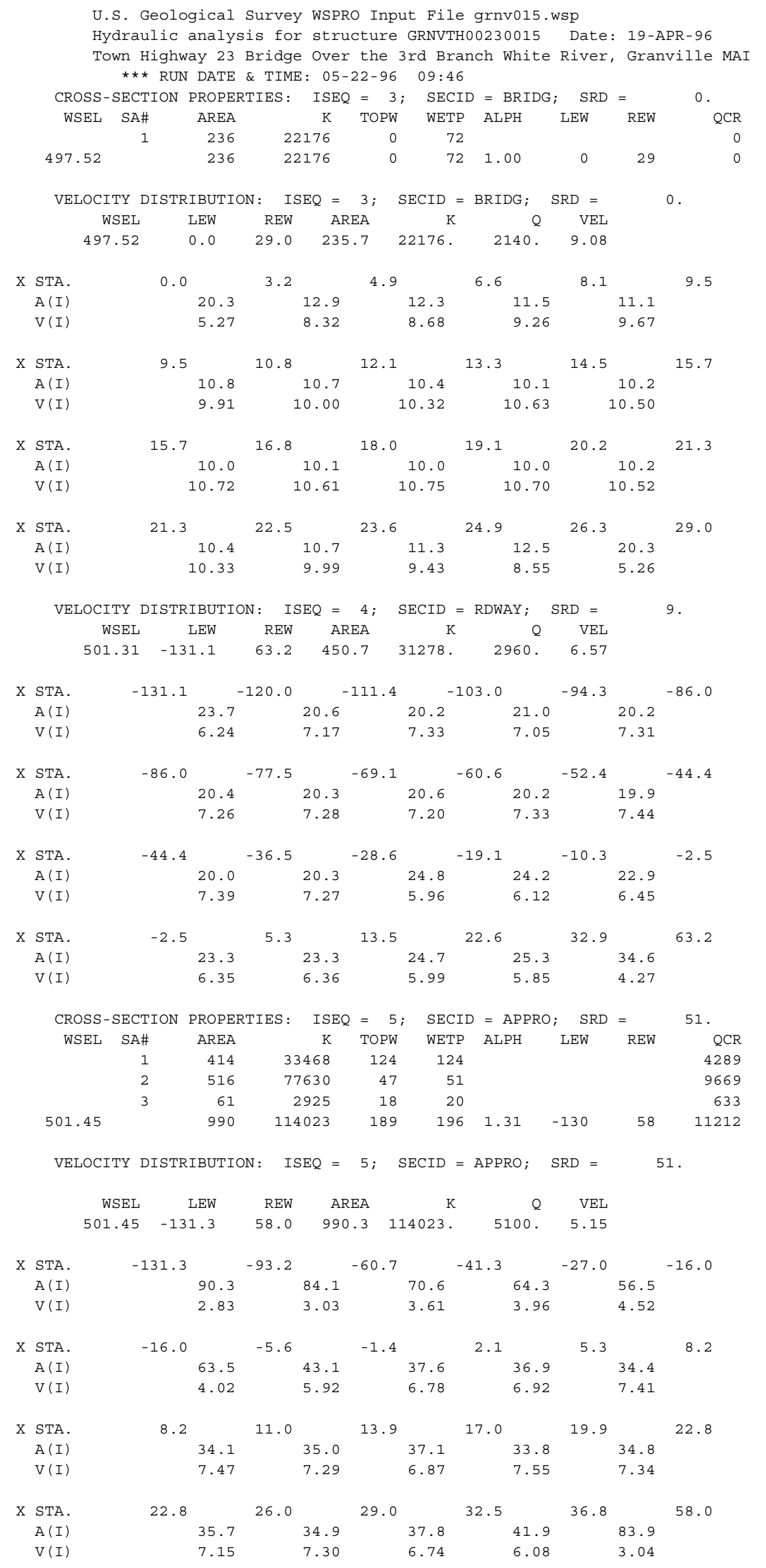


WSPRO OUTPUT FILE (continued)

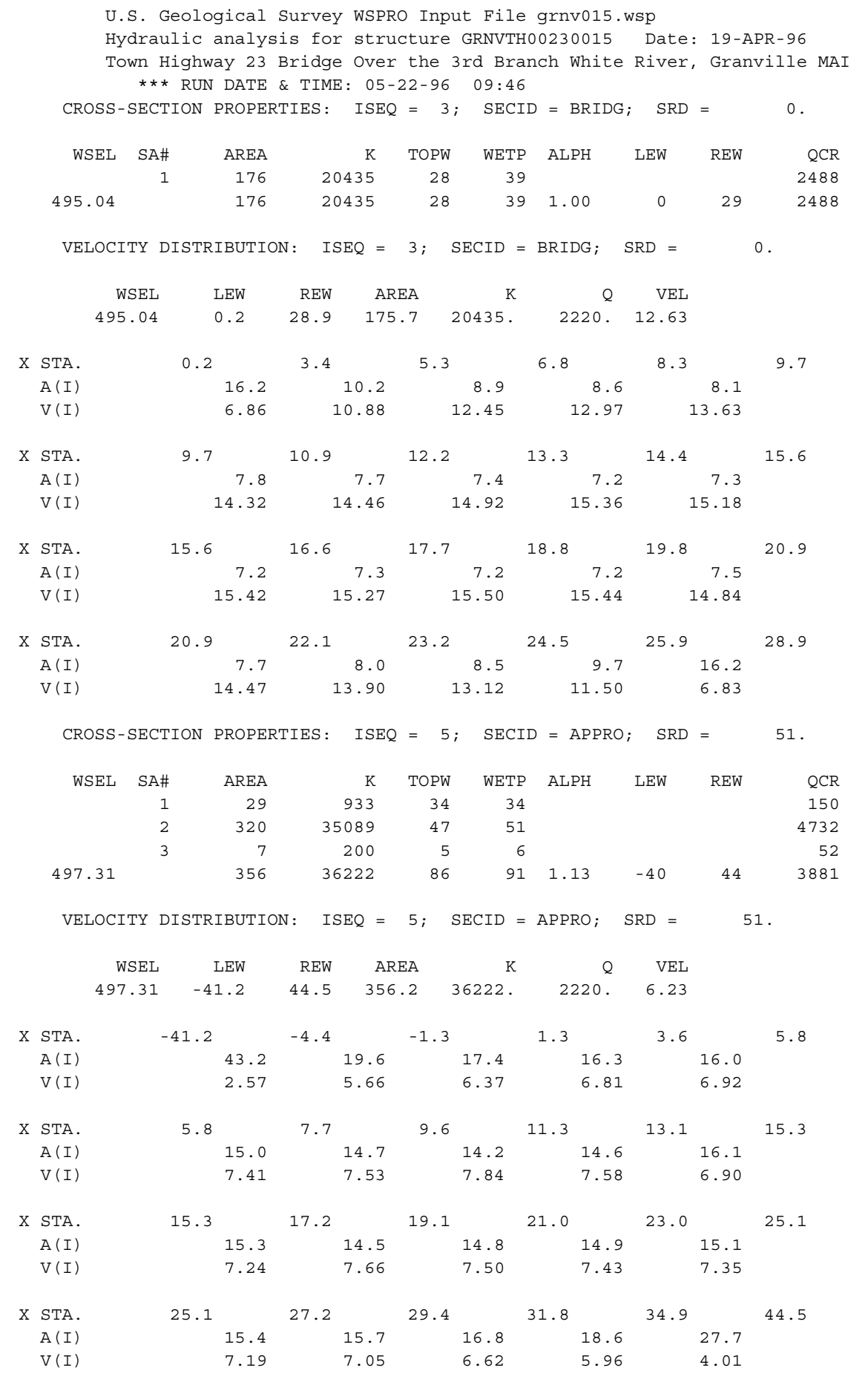


WSPRO OUTPUT FILE (continued)

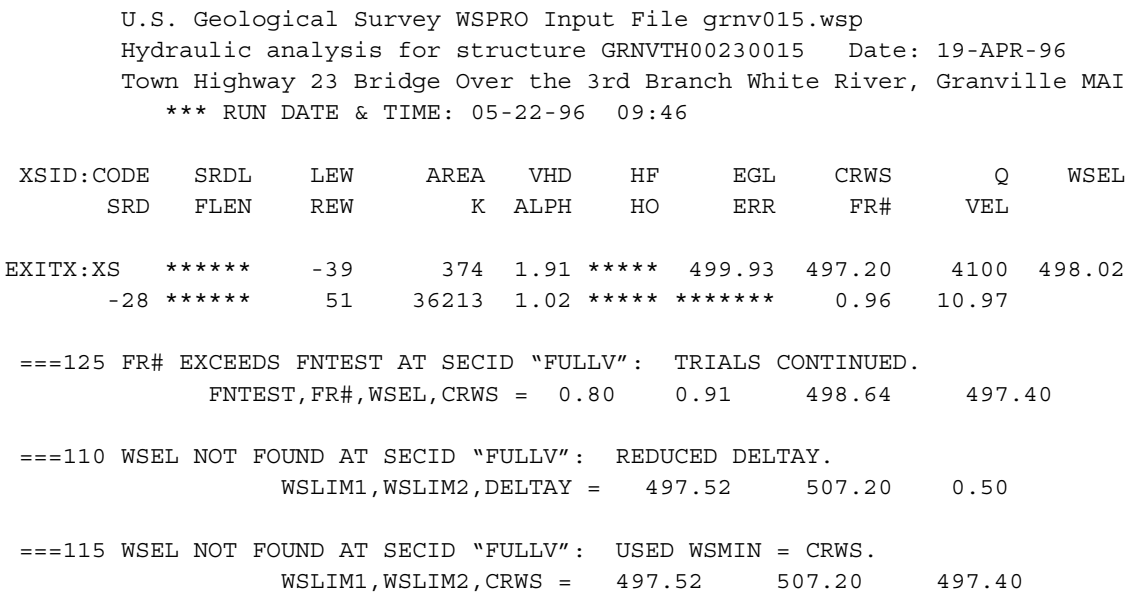

$\begin{array}{lcrrrrrrrr}\text { XSID : CODE } & \text { CRWS } & \text { FR\# } & \text { YMIN } & \text { YMAX } & \text { HF } & \text { HO } & \text { VHD } & \text { EGL } & \text { WSEL } \\ \text { EXITX:XS } & 497.20 & 0.96 & 488.17 & 507.00 * * * * * * * * * * * & 1.91 & 499.93 & 498.02 \\ \text { FULLV:FV } & 497.40 & 0.91 & 488.37 & 507.20 & 0.33 & 0.00 & 1.60 & 500.25 & 498.64 \\ \text { BRIDG : BR } & 494.75 & 0.61 & 488.06 & 497.52 * * * * * * * * * * * & 1.50 & 499.02 & 497.52 \\ \text { RDWAY:RG } & * * * * * * * * * * * * * * * & 498.27 & 509.04 & 0.08 * * * * * * & 0.51 & 501.06 & 500.59 \\ \text { APPRO:AS } & 497.12 & 0.48 & 489.11 & 510.15 & 0.15 & 0.00 & 0.51 & 501.13 & 500.62\end{array}$


WSPRO OUTPUT FILE (continued)

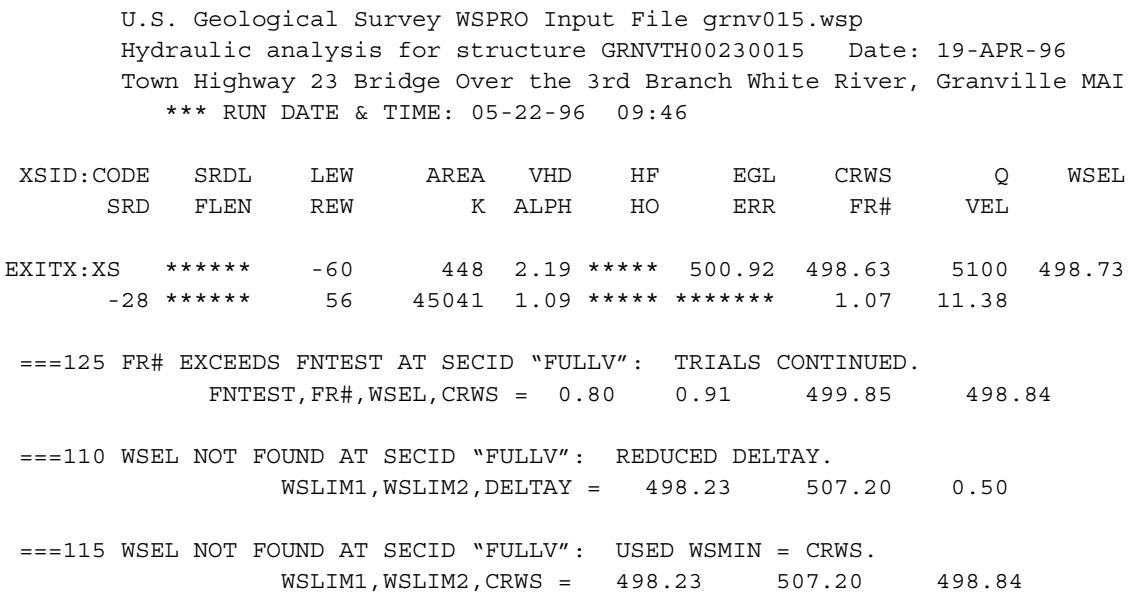

SECOND USER DEFINED TABLE.

$\begin{array}{lcrrrrrrrr}\text { XSID }: \text { CODE } & \text { CRWS } & \text { FR\# } & \text { YMIN } & \text { YMAX } & \text { HF } & \text { HO } & \text { VHD } & \text { EGL } & \text { WSEL } \\ \text { EXITX :XS } & 498.63 & 1.07 & 488.17 & 507.00 * * * * * * * * * * * & 2.19 & 500.92 & 498.73 \\ \text { FULLV : FV } & 498.84 & 0.92 & 488.37 & 507.20 & 0.27 & 0.00 & 1.34 & 501.17 & 499.84 \\ \text { BRIDG : BR } & 494.44 & 0.56 & 488.06 & 497.52 * * * * * * * * * * & 1.28 & 498.80 & 497.52 \\ \text { RDWAY : RG } & * * * * * * * * * * * * * * * & 498.27 & 509.04 & 0.08 * * * * * * & 0.54 & 501.91 & 501.31 \\ \text { APPRO : AS } & 498.17 & 0.46 & 489.11 & 510.15 & 0.15 & 0.00 & 0.54 & 501.99 & 501.45\end{array}$


WSPRO OUTPUT FILE (continued)

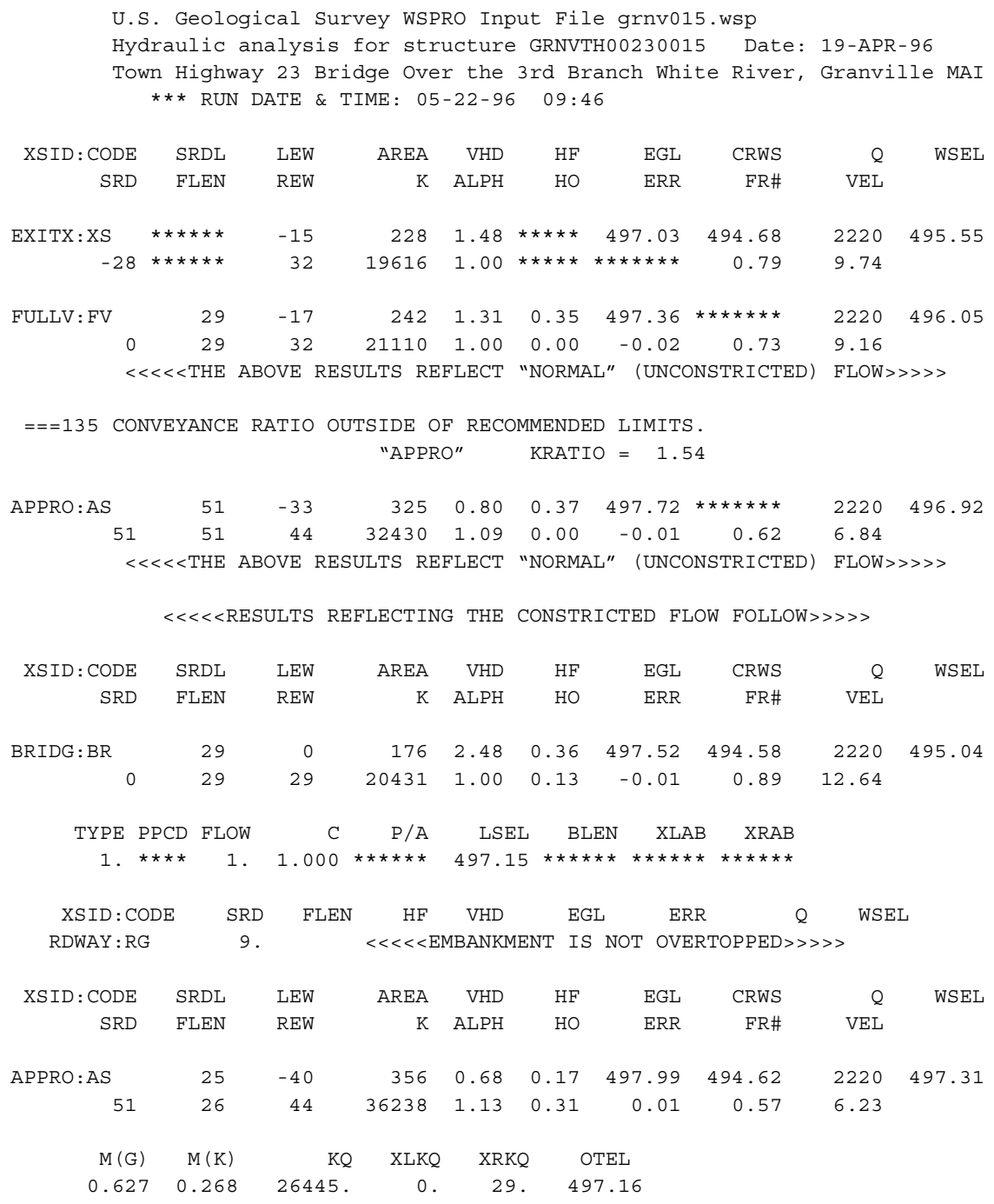

FIRST USER DEFINED TABLE.

\begin{tabular}{|c|c|c|c|c|c|c|c|c|}
\hline XSID : CODE & SRD & LEW & REW & Q & K & AREA & VEL & WSEL \\
\hline EXITX:XS & -29 & -16 & 32 . & 2220 . & 19616. & 228 & 9.74 & 495.55 \\
\hline FULLV : FV & 0 & -18 & 32 . & 2220 . & 21110 . & 242 . & 9.16 & 496.05 \\
\hline BRIDG : BR & 0 . & 0 & 29. & 2220 . & 20431 . & 176. & 12.64 & 495.04 \\
\hline RDWAY : RG & \multicolumn{3}{|c|}{ 9. $* * \star * * * \star * * * \star * \star * *$} & \multicolumn{3}{|c|}{ 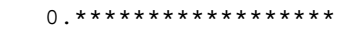 } & \multicolumn{2}{|c|}{$2.00 * * * * * * * *$} \\
\hline APPRO : AS & 51. & -41 & 44 & 2220 . & 36238 . & 356. & 6.23 & 497.31 \\
\hline XSID : CODE & XLKQ & XRKQ & & & & & & \\
\hline APPRO : AS & 0 . & 29. & 2644 & & & & & \\
\hline
\end{tabular}

SECOND USER DEFINED TABLE.

$\begin{array}{lcrrrrrrrr}\text { XSID :CODE } & \text { CRWS } & \text { FR\# } & \text { YMIN } & \text { YMAX } & \text { HF } & \text { HO } & \text { VHD } & \text { EGL } & \text { WSEL } \\ \text { EXITX:XS } & 494.68 & 0.79 & 488.17 & 507.00 * * * * * * * * * * * & 1.48 & 497.03 & 495.55 \\ \text { FULLV:FV } & * * * * * * * & 0.73 & 488.37 & 507.20 & 0.35 & 0.00 & 1.31 & 497.36 & 496.05 \\ \text { BRIDG:BR } & 494.58 & 0.89 & 488.06 & 497.52 & 0.36 & 0.13 & 2.48 & 497.52 & 495.04 \\ \text { RDWAY:RG } & * * * * * * * * * * * * * * * & 498.27 & 509.04 * * * * * * * * * * * * * * * * * * * * * * * * * * * * * \\ \text { APPRO:AS } & 494.62 & 0.57 & 489.11 & 510.15 & 0.17 & 0.31 & 0.68 & 497.99 & 497.31\end{array}$




\section{APPENDIX C:}

\section{BED-MATERIAL PARTICAL-SIZE DISTRIBUTION}




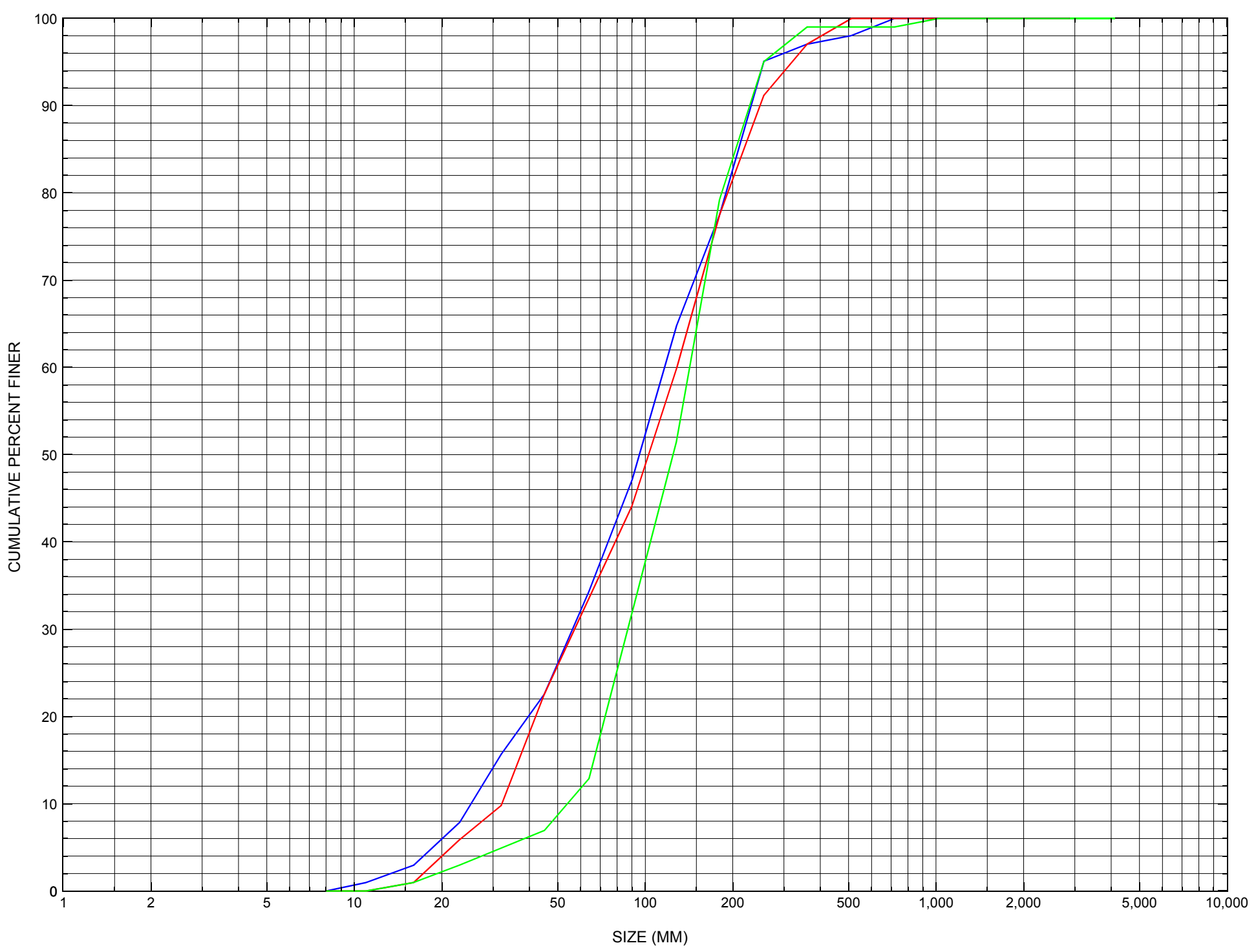

Appendix C. Bed material particle-size distributions for three pebble count transects at the approach cross-section for structure GRNVTH00230015, in Granville, Vermont. 


\section{APPENDIX D: \\ HISTORICAL DATA FORM}




\section{Structure Number GRNVTH00230015}

\section{General Location Descriptive}

Data collected by (First Initial, Full last name) $\underline{\text { M. IVANOFF }}$

Date $(M M / D D / Y Y) \_\mathbf{0 8} / \underline{\mathbf{2 6}} / \underline{\mathbf{9 4}}$

Highway District Number (I - 2; nn) 04

Town (FIPS place code; I - 4; nnnnn) $\mathbf{2 9 5 7 5}$

Waterway ( $I$ - 6) THIRD BRANCH WHITE R

Route Number $\underline{\text { TH023 }}$

Topographic Map Warren

Latitude (I - 16; nnnn.n) $\mathbf{4 4 0 0 8}$
County (FIPS county code; I - 3; nnn)

Mile marker (I - 11; nnn.nnn) $\mathbf{0 0 0 0 0 0}$

Road Name (I - 7): -

Vicinity (I - 9) AT JCT TH 23 + VT 12A

Hydrologic Unit Code: $\mathbf{0 1 0 8 0 1 0 5}$

Longitude (i - 17; nnnnn.n) $\mathbf{7 2 4 5 2}$

\section{Select Federal Inventory Codes}

FHWA Structure Number (I - 8) 10010700150107

Maintenance responsibility $(I-21 ; n n) \_$03_ Maximum span length $(I-48 ; n n n n) \underline{\mathbf{0 0 3 1}}$

Year built (I - 27; YYYY) 1919

Structure length (I - 49; nnnnnn) $\underline{000035}$

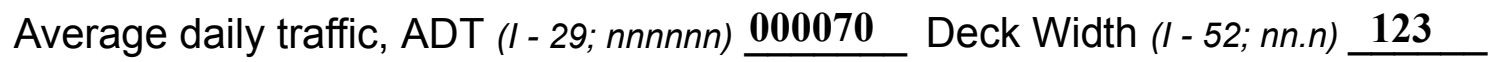

Year of ADT (I - 30; YY) $\underline{\mathbf{9 1}}$

Channel \& Protection $(I-61 ; n) \underline{\mathbf{6}}$

Opening skew to Roadway $(I-34 ; n n) \quad 12$

Waterway adequacy $(I-71 ; n) \underline{6}$

Operational status $(I-41 ; X) \quad \mathbf{B}$

Underwater Inspection Frequency $(I-92 B ; X Y Y) \_\mathbf{N}$

Structure type (I- 43; nnn) $\mathbf{3 0 2}$

Year Reconstructed (I - 106) 1955

Approach span structure type (I - 44; nnn) $\mathbf{0 0 0}$ Clear span (nnn.n ft) _ _

Number of spans (I - 45; nnn) $\mathbf{0 0 1}$

Vertical clearance from streambed (nnn.n ft) $\underline{\mathbf{0 0 8 . 5}}$

Number of approach spans (I - 46; nnnn) $\mathbf{0 0 0 0}$

Waterway of full opening $\left(n n n . n \mathrm{ft}^{2}\right)$

Comments:

Structural report of 4/21/93 indicates a steel beam and timber deck type bridge with a narrow gravel roadway approach. The bridge has concrete abutment walls and wingwalls. The right abutment has some areas where it has eroded away leaving some deep pockets, one foot deep, at the streambed level. No settlement was reported. The channel makes a moderate turn into bridge with most of the flow along right abutment. The banks are well protected with no embankment erosion. No drift/vegetation build up near bridge. 


\section{Bridge Hydrologic Data}

Is there hydrologic data available? $\underline{\mathbf{N}}$ if No, type ctrl-n $h \quad$ VTAOT Drainage area $\left(m i^{2}\right)$ : -

Terrain character:

Stream character \& type: -

Streambed material: Stone and gravel

Discharge Data (cfs): $\quad Q_{2.33}$

$$
\mathrm{Q}_{50}-
$$

Record flood date $(M M / D D / Y Y):-$

$$
\begin{array}{ll}
Q_{10} \_- & Q_{25} \_ \\
Q_{100 \_-} & Q_{500 \_}-
\end{array}
$$

Water surface elevation $(f t):-$

Estimated Discharge (cfs): Velocity at $\mathrm{Q}-$ $(\mathrm{ft} / \mathrm{s}):$

Ice conditions (Heavy, Moderate, Light) : -

Debris (Heavy, Moderate, Light):

The stage increases to maximum highwater elevation (Rapidly, Not rapidly):

The stream response is (Flashy, Not flashy):

Describe any significant site conditions upstream or downstream that may influence the stream's stage: -

Watershed storage area (in percent): - _ \%

The watershed storage area is: - (1-mainly at the headwaters; 2- uniformly distributed; 3-immediatly upstream oi the site)

Water Surface Elevation Estimates for Existing Structure:

\begin{tabular}{|l|l|l|l|l|l|}
\hline Peak discharge frequency & $Q_{2.33}$ & $Q_{10}$ & $Q_{25}$ & $Q_{50}$ & $Q_{100}$ \\
Water surface elevation (ft)) & - & - & - & - & - \\
Velocity (ft/sec) & - & - & - & - & - \\
\hline
\end{tabular}

Long term stream bed changes: -

Is the roadway overtopped below the $\mathrm{Q}_{100}$ ? (Yes, No, Unknown): $\mathbf{U} \quad$ Frequency: Relief Elevation $(f t)$ :

Discharge over roadway at $Q_{100}\left(f^{3} / \mathrm{sec}\right)$ :

Are there other structures nearby? (Yes, No, Unknown): $\mathbf{U}$ Upstream distance (miles): Town: If No or Unknown, type ctrl-n os Highway No. : Structure No. : Year Built:

Clear span (ft): Clear Height (ft): Full Waterway $\left(f t^{2}\right)$ : 
Downstream distance (miles): Town: Year Built:

Highway No. : Structure No. : Structure Type:

Clear span (ft): Clear Height $(f t)$ : Full Waterway $\left(f t^{2}\right)$ :

Comments:

--

\section{USGS Watershed Data}

Watershed Hydrographic Data

Drainage area $(D A) \stackrel{23.57}{\mathrm{mi}^{2}}$

Lake and pond area $\mathbf{0 . 0 2}$ $\mathrm{mi}^{2}$

Watershed storage (ST) 0.1

Bridge site elevation 820 $\mathrm{ft}$ $\%$

Main channel length 8.44 mi $10 \%$ channel length elevation 850 $\mathrm{ft} \quad 85 \%$ channel length elevation $\mathrm{ft}$

Main channel slope $(S)$
(S) 134.28 $\mathrm{ft} / \mathrm{mi}$

Watershed Precipitation Data

Average site precipitation in Average headwater precipitation in

Maximum 2yr-24hr precipitation event $(124,2)$ in

Average seasonal snowfall (Sn) $\mathrm{ft}$ 


\section{Bridge Plan Data}

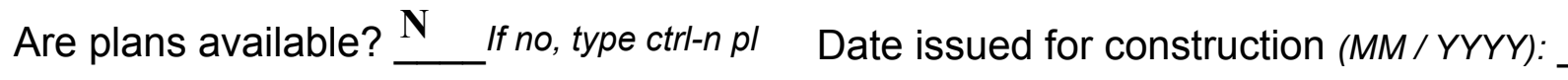

Project Number

Minimum channel bed elevation:

Low superstructure elevation: USLAB DSLAB USRAB DSRAB Benchmark location description:

NO BENCHMARK INFORMATION

Reference Point (MSL, Arbitrary, Other): Datum (NAD27, NAD83, Other):

Foundation Type: 4

If 1: Footing Thickness

If 2: Pile Type: (1-Wood; 2-S

(1-

(1-Spreadfooting; 2-Pile; 3- Gravity; 4-Unknown)

Footing bottom elevation:

If 3 : Footing bottom elevation:
Is boring information available?

Foundation Material Type: $\mathbf{3}$

Briefly describe material at foundation bottom elevation or around piles:

NO FOUNDATION MATERIAL INFORMATION

Comments:

NO PLANS. 


\section{Cross-sectional Data}

Is cross-sectional data available? $\mathbf{N}$ If no, type ctrl-n xs

Source (FEMA, VTAOT, Other)? -

Comments: NO CROSS SECTION INFORMATION

\begin{tabular}{|l|l|l|l|l|l|l|l|l|l|l|l|}
\hline Station & - & - & - & - & - & - & - & - & - & - & - \\
\hline Feature & - & - & - & - & - & - & - & - & - & - & - \\
\hline $\begin{array}{l}\text { Low cord } \\
\text { elevation }\end{array}$ & - & - & - & - & - & - & - & - & - & - & - \\
\hline $\begin{array}{l}\text { Bed } \\
\text { elevation }\end{array}$ & - & - & - & - & - & - & - & - & - & - & - \\
\hline $\begin{array}{l}\text { Low cord to } \\
\text { bed length }\end{array}$ & - & - & - & - & - & - & - & - & - & - & - \\
\hline Station & - & - & - & - & - & - & - & - & - & - & - \\
\hline Feature & - & - & - & - & - & - & - & - & - & - & - \\
\hline $\begin{array}{l}\text { Low cord } \\
\text { elevation }\end{array}$ & - & - & - & - & - & - & - & - & - & - & - \\
\hline $\begin{array}{l}\text { Bed } \\
\text { elevation }\end{array}$ & - & - & - & - & - & - & - & - & - & - & - \\
\hline $\begin{array}{l}\text { Low cord to } \\
\text { bed length }\end{array}$ & - & - & - & - & - & - & - & - & - & - & - \\
\hline
\end{tabular}

Source (FEMA, VTAOT, Other)?

Comments: NO CROSS SECTION INFORMATION

\begin{tabular}{|l|l|l|l|l|l|l|l|l|l|l|l|}
\hline Station & - & - & - & - & - & - & - & - & - & - & - \\
\hline Feature & - & - & - & - & - & - & - & - & - & - & - \\
\hline $\begin{array}{l}\text { Low cord } \\
\text { elevation }\end{array}$ & - & - & - & - & - & - & - & - & - & - & - \\
\hline $\begin{array}{l}\text { Bed } \\
\text { elevation }\end{array}$ & - & - & - & - & - & - & - & - & - & - & - \\
\hline $\begin{array}{l}\text { Low cord to } \\
\text { bed length }\end{array}$ & - & - & - & - & - & - & - & - & - & - & - \\
\hline Station & - & - & - & - & - & - & - & - & - & - & - \\
\hline Feature & - & - & - & - & - & - & - & - & - & - & - \\
\hline $\begin{array}{l}\text { Low cord } \\
\text { elevation }\end{array}$ & - & - & - & - & - & - & - & - & - & - & - \\
\hline $\begin{array}{l}\text { Bed } \\
\text { elevation }\end{array}$ & - & - & - & - & - & - & - & - & - & - & - \\
\hline $\begin{array}{l}\text { Low cord to } \\
\text { bed length }\end{array}$ & - & - & - & - & - & - & - & - & - & - & - \\
\hline
\end{tabular}




\section{APPENDIX E: \\ LEVEL I DATA FORM}


U. S. Geological Survey

Bridge Field Data Collection and Processing Form

Qa/Qc Check by: MAW Date: $02 / 10 / 95$

\section{Structure Number GRNVTH00230015} Computerized by: MAI Date: $\underline{03 / 15 / 95}$

Reviewd by: MAL Date: $\underline{\mathbf{0 5} / \mathbf{1 3} / 95}$

\section{A. General Location Descriptive}

1. Data collected by (First Initial, Full last name) $\mathbf{S}$. OLSON

Date $(M M / D D / Y Y)$

10 / $21 / 1994$

2. Highway District Number 04

Mile marker $\underline{0}$

County ADDISON (001)

Waterway (I - 6) THIRD BRANCH WHITE RIVER

Town GRANVILLE (29575)

Route Number TH023

Road Name -

3. Descriptive comments:

Hydrologic Unit Code: $\mathbf{0 1 0 8 0 1 0 5}$

Near junction of TH 23 and VT 12A.

\section{B. Bridge Deck Observations}
4. Surface cover... LBUS 4
RBUS 5
LBDS 2
RBDS 2
Overall 2

(2b us, ds,lb,rb: 1- Urban; 2- Suburban; 3- Row crops; 4- Pasture; 5- Shrub- and brushland; 6- Forest; 7- Wetland)
5. Ambient water surface...US $\underline{2}$
UB 2
DS 2
(1- pool; 2- riffle)

6. Bridge structure type 1 (1- single span; 2- multiple span; 3- single arch; 4- multiple arch; 5-cylindrical culvert; 6- box culvert; or 7- other)
7. Bridge length $\mathbf{3 5}$
(feet)
Span length $\underline{\mathbf{3 1}}$
(feet)
Bridge width 12.3 (feet)

\section{Road approach to bridge:}
8. LB 0
RB 2
( 0 even, 1- lower, 2- higher)
9. LB 2
RB $\underline{2}$
(1- Paved, 2- Not paved)

10. Embankment slope (run / rise in feet / foot)

US left

0.0:1

US right

0.0:1

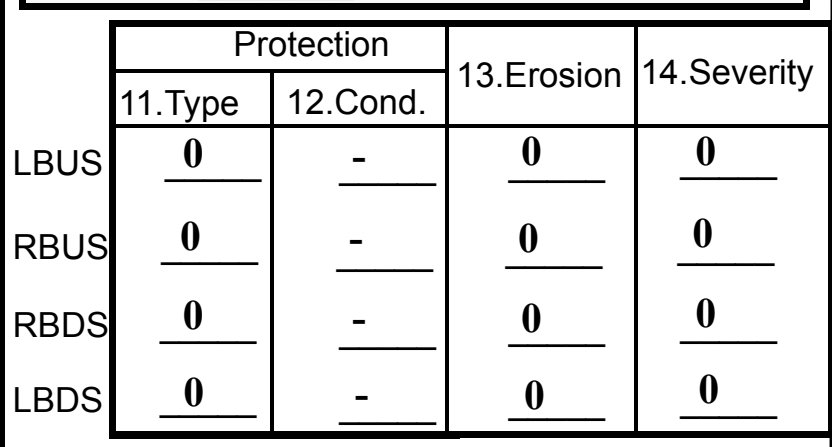

Bank protection types: 0- none; 1- < 12 inches;

2- < 36 inches; 3- < 48 inches;

4- < 60 inches; 5- wall / artificial levee

Bank protection conditions: 1- good; 2- slumped;

3- eroded; 4- failed

Erosion: 0 - none; 1- channel erosion; 2

road wash; 3- both; 4- other

Erosion Severity: 0 - none; 1- slight; 2- moderate; 3- severe

\section{Channel approach to bridge (BF):}

15. Angle of approach: $\mathbf{5}$

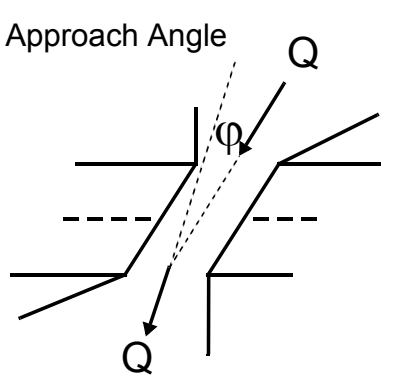

17. Channel impact zone 1 :

Where? RB (LB, RB)

Range? 9 feet US

Channel impact zone 2:

Where? RB (LB, RB)

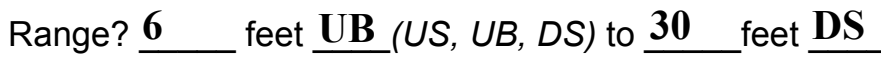

Impact Severity: 0- none to very slight; 1- Slight; 2- Moderate; 3- Severe 
18. Level II Bridge Type: 1a

1a- Vertical abutments with wingwalls

$1 \mathrm{~b}$ - Vertical abutments without wingwalls

2- Vertical abutments and wingwalls, sloping embankment Wingwalls perpendicular to abut. face

3- Spill through abutments

4- Sloping embankment, vertical wingwalls and abutments

Wingwall angle less than $90^{\circ}$.

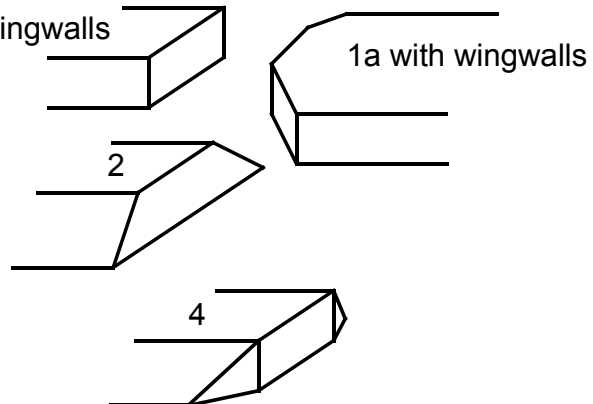

19. Bridge Deck Comments (surface cover variations, measured bridge and span lengths, bridge type variations, approach overflow width, etc.)

4. LBUS: shrubs and brush with some trees on the immediate bank then pasture. RBUS is shrubs/brush. At two bridge lengths landward there is railroad tracks and VT 12. LBDS is suburban for a short distance downstream; becomes forest about $70 \mathrm{ft}$. RBDS: there is a large house surrounded by brush type vegetation. 7. Values from VTAOT database (VTAOT, written communication, August 26, 1994). Measured bridge length: 35, span: 29, and width: 12 feet.

\section{Upstream Channel Assessment}

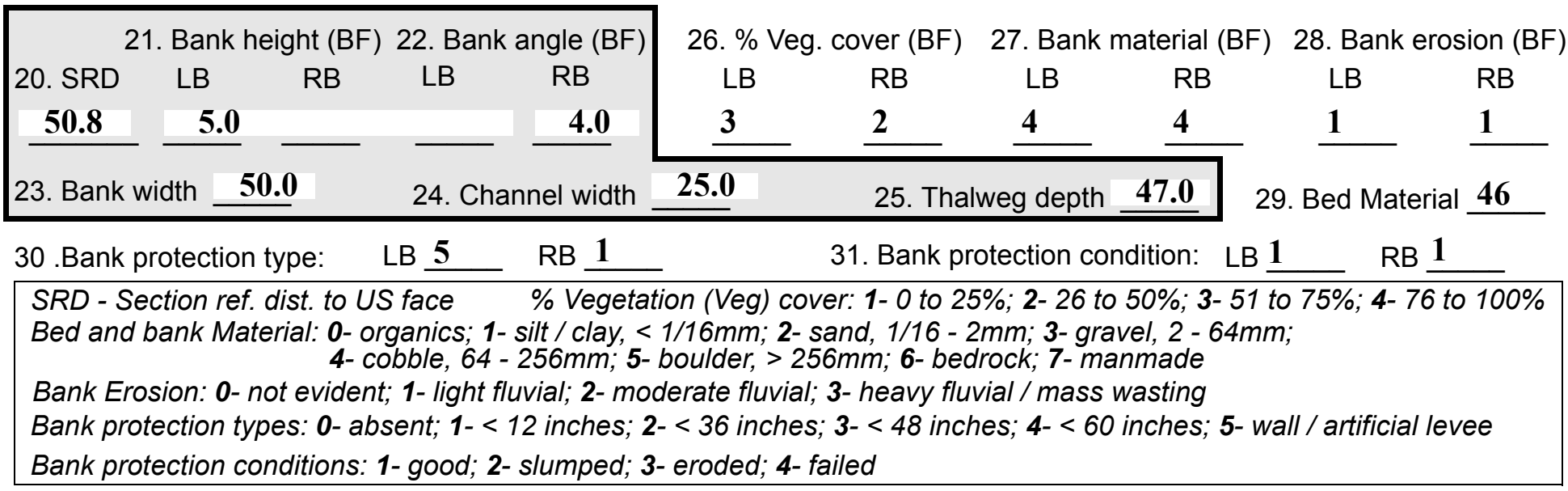

32. Comments (bank material variation, minor inflows, protection extent, etc.):

29. Bed material is bedrock from about 30 to 105 feet upstream and cobbles.

30. LB: some protection from a cinder block wall extending $45 \mathrm{ft}$. upstream. RB: stone fill extends $40 \mathrm{ft}$. from the bridge. 

feet US (US, UB) to $\mathbf{1 2 0}$ feet $\underline{\text { US }}$ (US, UB, DS) positioned $\underline{\mathbf{0}}$ $\%$ LB to $15 \%$ RB

37. Material: 4

38. Point or side bar comments (Circle Point)or Side; Note additional bars, material variation, status, etc.):

There are a few boulders on point bar as well. Its a small point bar on the inside of a bend. A much larger point bar exist on the right bank opposite of the described cut bank.

39. Is a cut-bank present? $\mathbf{Y}$ (Y or if $N$ type ctrl-n cb) 40. Where? $\underline{\mathbf{L B}}$ (LB or $R B)$

41. Mid-bank distance: $\mathbf{2 0 0}$ 42. Cut bank extent: $\underline{\mathbf{1 2 0}}$ feet $\underline{\mathrm{US}}$

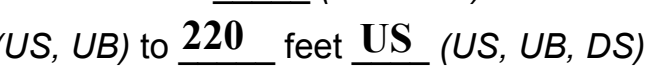

43. Bank damage: 2 (1- eroded and/or creep; 2- slip failure; 3- block failure)

44. Cut bank comments (eg. additional cut banks, protection condition, etc.):

Beyond the two bridge length range.

\section{Is channel scour present? $\mathbf{Y}$ ( $Y$ or if $N$ type ctrl-n $c s$ )}

47. Scour dimensions: Length $\mathbf{2 0}$ Width 8 Depth : 2

46. Mid-scour distance: 60

48. Scour comments (eg. additional scour areas, local scouring process, etc.):

It is a scour hole completely bounded by bedrock.

\section{Are there major confluences? $\mathbf{N}$}

51. Confluence 1: Distance Confluence 2: Distance 52. Enters on Enters on 54. Confluence comments (eg. confluence name):

NO MAJOR CONFLUENCES

\section{NO MAJOR CONFLUENCES}

( $Y$ or if $N$ type ctrl-n mc) ( $(L B$ or $R B)$ (LB or $R B)$
50. How many? -

53. Type(1-perennial; 2- ephemeral)

Type (1- perennial; 2- ephemeral)

\section{Under Bridge Channel Assessment}

55. Channel restraint (BF)? LB 2

56. Height (BF)
LB RB
$\mathbf{2 8 . 5}-$
58. Bank width (BF) -

59. Channel width $(\mathrm{Amb})$

61. Material (BF)

LB RB

$\underline{2} \quad \underline{7}$

(1- natural bank; 2- abutment; 3- artificial levee)

Bed and bank Material: 0- organics; 1- silt / clay, < 1/16mm; 2- sand, 1/16 - 2mm; 3- gravel, 2 - 64mm; 4- cobble, 64 - 256mm; 5- boulder, > 256mm; 6- bedrock; 7- manmade

Bank Erosion: 0- not evident; 1- light fluvial; 2- moderate fluvial; 3- heavy fluvial / mass wasting

64. Comments (bank material variation, minor inflows, protection extent, etc.):

4

The right abutment is cracked and a few pieces of the abutment are missing, exposing a part of a stone abutment wall. Further weathering of the concrete is visible at an impact point near the downstream face on the right abutment. The concrete of the abutment is cut into 4 to 5 inches horizontally exposing drywall.

There is some slight channel deepening under the bridge (about 0.5 feet determined from survey data), however length and width of 'scour' is not clearly visible; it is either long term or contraction scour.

63. There are some boulders and native material in the channel. 
65. Debris and Ice Is there debris accumulation?

67. Debris Potential 1 (1- Low; 2- Moderate; 3- High)

69. Is there evidence of ice build-up? $\underline{2}(Y$ or $N)$

70. Debris and Ice Comments:

1

65. Some slight debris caught on a tree on the left bank just upstream of the bridge.

67. Upstream is laterally stable, has few cut banks, and consists of cobble and boulder type material.

68. Moderate channel gradient and the span length is $60 \%$ of the upstream bank width.

\begin{tabular}{|l|c|c|c|c|c|c|c|c|}
\hline Abutments & $\begin{array}{c}\text { 71. Attack } \\
\angle \text { (BF) }\end{array}$ & $\begin{array}{c}\text { 72. Slope } \angle \\
\text { (Qmax) }\end{array}$ & $\begin{array}{c}\text { 73. Toe } \\
\text { loc. (BF) }\end{array}$ & $\begin{array}{c}\text { 74. Scour } \\
\text { Condition }\end{array}$ & $\begin{array}{c}75 . \text { Scour } \\
\text { depth }\end{array}$ & $\begin{array}{c}\text { 76. Exposure } \\
\text { depth }\end{array}$ & 77. Material & 78. Length \\
\hline LABUT & & - & $\mathbf{8 3}$ & $\mathbf{2}$ & $\mathbf{0}$ & - & - & $\mathbf{9 0 . 0}$ \\
\hline RABUT & $\mathbf{1}$ & $\mathbf{5}$ & $\mathbf{9 0}$ & & & $\mathbf{2}$ & $\mathbf{0}$ & $\mathbf{2 9 . 0}$ \\
\hline
\end{tabular}

Pushed: $L B$ or RB

Toe Location (Loc.): 0- even, 1- set back, 2- protrudes

Scour cond.: 0- not evident; 1- evident (comment); 2- footing exposed; 3-undermined footing; 4- piling exposed; 5- settled; 6- failed

Materials: 1- Concrete; 2- Stone masonry or drywall; 3- steel or metal; 4- wood

79. Abutment comments (eg. undermined penetration, unusual scour processes, debris, etc.):

$-$

1

See previous comments in 64.

75. RABUT: There is no footing along the abutment. Apparently the concrete covers part of an old stonewall abutment. Some of the concrete is eroded away especially along the base of the abutment exposing the stone drywall. In one spot there is nearly a foot between the streambed and the concrete; a hole has formed $0.5 \mathrm{ft}$. deep into the abutment. However, the stone drywall exposed at the base does not appear to be undermined.

80. Wingwalls:

Exist? Material? Scour Scour Exposure $\begin{aligned} & 81 . \\ & \text { Angle? Length? }\end{aligned}$ Condition? depth? depth?

USLWW:

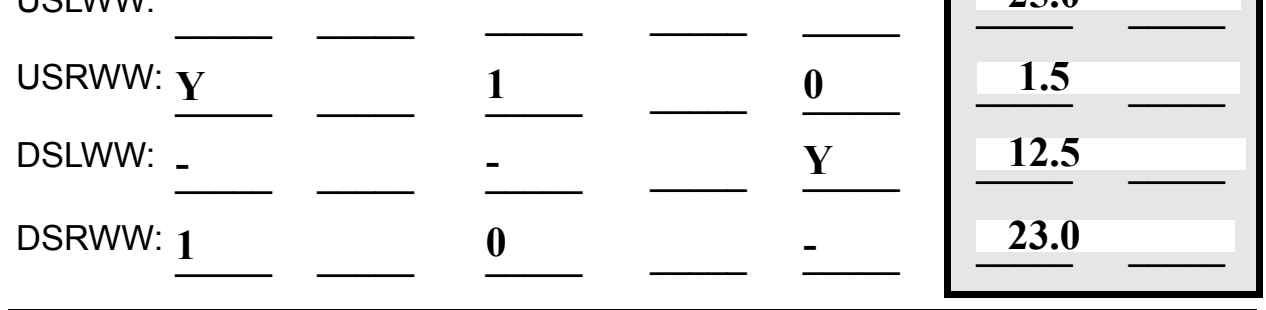

Wingwall materials: 1- Concrete; 2- Stone masonry or drywall; 3- steel or metal; 4- wood

82. Bank / Bridge Protection:

\begin{tabular}{|l|l|l|l|l|l|l|l|c|}
\hline Location & USLWW & USRWW & LABUT & RABUT & LB & RB & DSLWW & DSRWW \\
\hline Type & - & $\mathbf{0}$ & $\mathbf{N}$ & - & $\mathbf{1}$ & $\mathbf{1}$ & - & $\mathbf{2}$ \\
\hline Condition & $\mathbf{Y}$ & - & - & - & $\mathbf{2}$ & $\mathbf{1}$ & - & $\mathbf{1}$ \\
\hline Extent & $\mathbf{1}$ & - & - & $\mathbf{5}$ & $\mathbf{1}$ & $\mathbf{0}$ & $\mathbf{1}$ & - \\
\hline
\end{tabular}

Bank / Bridge protection types: 0- absent; 1- < 12 inches; 2- < 36 inches; 3- < 48 inches; 4- < 60 inches; 
83. Wingwall and protection comments (eg. undermined penetration, unusual scour processes, etc.):

$-$

$-$

$-$

$-$

$-$

5

1

3

$-$

\section{Piers:}

84. Are there piers? $\mathbf{8 0 .}$ ( $Y$ or if $N$ type ctrl-n pr)

\begin{tabular}{|l|c|c|c|c|l|l|l|}
\hline \multirow{2}{*}{$\begin{array}{l}85 . \\
\text { Pier no. }\end{array}$} & \multicolumn{3}{|c|}{ width (w) feet } & \multicolumn{3}{|c|}{ elevation (e) feet } \\
\cline { 2 - 8 } & w1 & w2 & w3 & e@w1 & e@w2 & e@w3 \\
\hline Pier 1 & & & & $\mathbf{7 0 . 0}$ & $\mathbf{1 0 . 5}$ & $\mathbf{5 5 . 0}$ \\
\hline Pier 2 & $\mathbf{8 . 0}$ & $\mathbf{5 . 0}$ & - & $\mathbf{6 0 . 0}$ & - & - \\
\hline Pier 3 & - & - & - & - & - & - \\
\hline Pier 4 & - & - & - & - & - & - \\
\hline
\end{tabular}

\begin{tabular}{|l|l|l|l|l|}
\hline Level 1 Pier Descr. & \multicolumn{1}{|c|}{1} & \multicolumn{1}{|c|}{2} & \multicolumn{1}{|c|}{3} & \multicolumn{1}{|c|}{4} \\
\hline 86. Location (BF) & US & $\mathbf{8 2 .}$ & nstre & g the \\
\hline 87. Type & Left & RAB & am & right \\
\hline 88. Material & and & UT: & end & abut \\
\hline 89. Shape & Righ & Ther & of & ment \\
\hline 90. Inclined? & t & e is a & the & base \\
\hline 91. Attack $\angle$ (BF) & wing & woo & right & is \\
\hline 92. Pushed & wall: & den/ & abut & dow \\
\hline 93. Length (feet) & - & - & - & - \\
\hline 94. \# of piles & see & log & ment & ngra \\
\hline 95. Cross-members & com- & wall & .The & ded \\
\hline 96. Scour Condition & ment & at & stone & to \\
\hline 97. Scour depth & s in & the & fill & slum \\
\hline 98. Exposure depth & $\mathbf{7 9 .}$ & dow & alon & ped \\
\hline
\end{tabular}

LFP, LTB, LB, MCL, MCM, MCR, RB, RTB, RFP

1- Solid pier, 2- column, 3- bent

1- Wood; 2- concrete; 3- metal; 4- stone

1- Round; 2- Square; 3- Pointed

Y-yes; $N-$ no

$L B$ or $R B$

0- none; 1- laterals; 2- diagonals; 3- both

0- not evident; 1- evident (comment);

2- footing exposed; 3- piling exposed;

4- undermined footing; 5 - settled; 6 - failed 
99. Pier comments (eg. undermined penetration, protection and protection extent, unusual scour processes, etc.):

because if it was placed along the abutment it has now slid into the channel and is only protecting the bed at the abutment toe. Furthermore, the protection is quite sparse. Abutment damage has occurred.

$\mathbf{N}$

$-$

100.

\section{E. Downstream Channel Assessment}

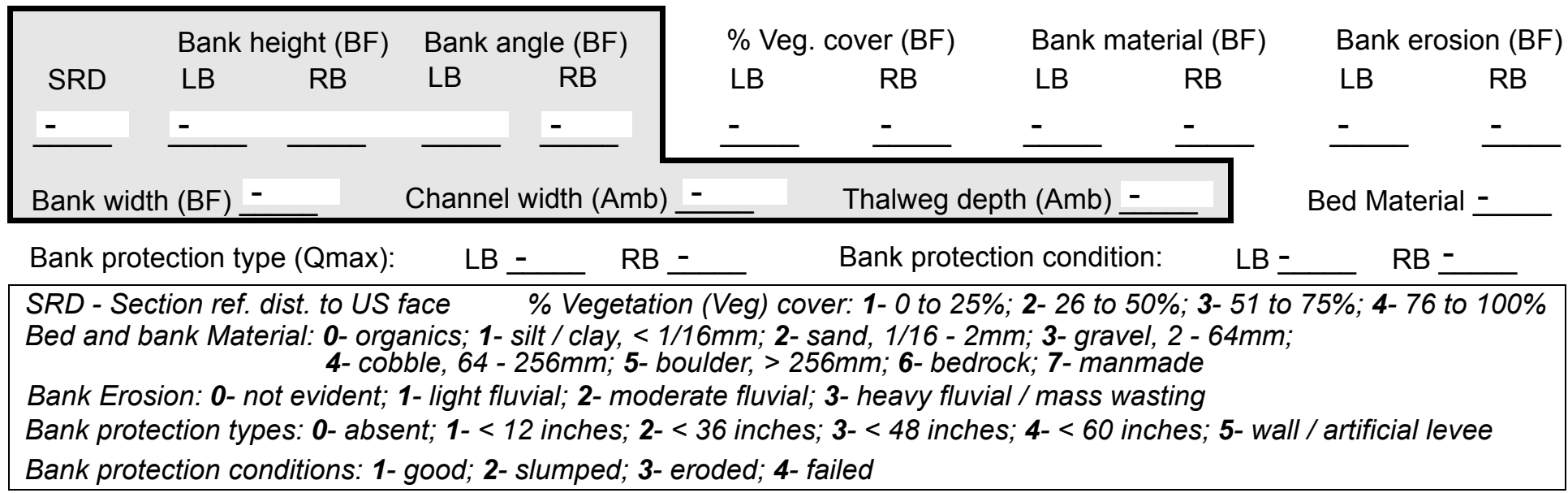

Comments (eg. bank material variation, minor inflows, protection extent, etc.):$$
-
$$$$
-
$$

-

-

-

-

-

-

-

-

-

-

-

-

-

101. Is a drop structure present? _ ( $Y$ or $N$, if $N$ type ctrl-n ds) 102. Distance: __ feet
103. Drop: - feet
104. Structure material: -
(1- steel sheet pile; 2- wood pile; 3- concrete; 4- other)

105. Drop structure comments (eg. downstream scour depth): 
106. Point/Side bar present? (Y or N. if $N$ type ctrl-n pb)Mid-bar distance: -

Mid-bar width: -

Point bar extent: feet -

(US, UB, DS) to feet (US, UB, DS) positioned $\%$ LB to $\% \mathrm{RB}$

Material:

Point or side bar comments (Circle Point or Side, note additional bars, material variation, status, etc.):

$-$

\section{NO PIERS}

Is a cut-bank present? ( $Y$ or if $N$ type ctrl-n cb) Where? (LB or $R B)$

Mid-bank distance:

Cut bank extent: feet (US, UB, DS) to feet (US, UB, DS)

Bank damage: (1- eroded and/or creep; 2- slip failure; 3- block failure)

Cut bank comments (eg. additional cut banks, protection condition, etc.):

1
1
4

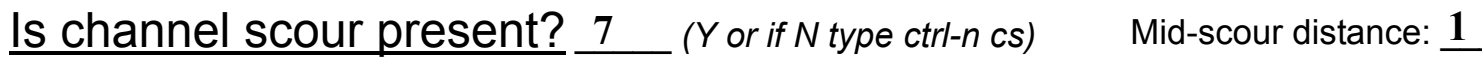
Scour dimensions: Length $\underline{\mathbf{0}}$ Width $\underline{4}$ Depth: $\underline{\mathbf{5}} \quad$ Positioned $\underline{\mathbf{5}}$ \%LB to $\underline{\mathbf{1}}$ \%RB Scour comments (eg. additional scour areas, local scouring process, etc.): 1

Bank protection LB: protection by a masonry wall extending from the end of the DS wingwall to $10 \mathrm{ft}$. Additional stone fill extends another 20 feet. RB: protected by a log crib wall about five feet tall and extending from the right abutment to $105 \mathrm{ft}$. downstream; extensive stone fill extends beyond the crib-work another 50 Are there major confluences? $\mathbf{7 5}$ (Y or if $N$ type ctrl-n $m c) \quad$ How many? feet.

Confluence 1: Distance The Enters on crib (LB or RB) Type (1- perennial; 2- ephemeral) Confluence 2: Distance work Enters on wall (LB or RB) Type alon (1- perennial; 2- ephemeral) Confluence comments (eg. confluence name):

g the right bank shows signs of undermining but in general is in good shape; undermined a foot in some locations.

\section{F. Geomorphic Channel Assessment}

1- Constructed

2- Stable

3- Aggraded

4- Degraded

5- Laterally unstable

6- Vertically and laterally unstable 
108. Evolution comments (Channel evolution not considering bridge effects; See HEC-20, Figure 1 for geomorphic descriptors):

N

$-$

NO DROP STRUCTURE 


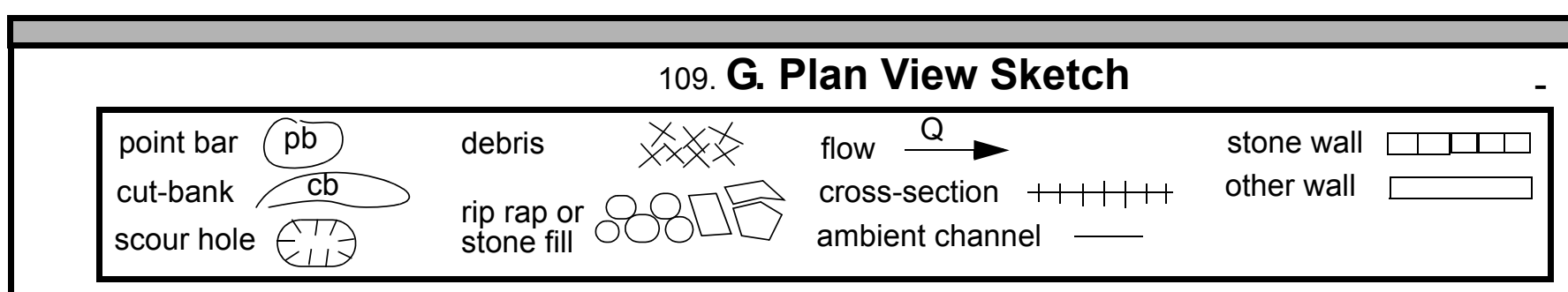


APPENDIX F:

SCOUR COMPUTATIONS 


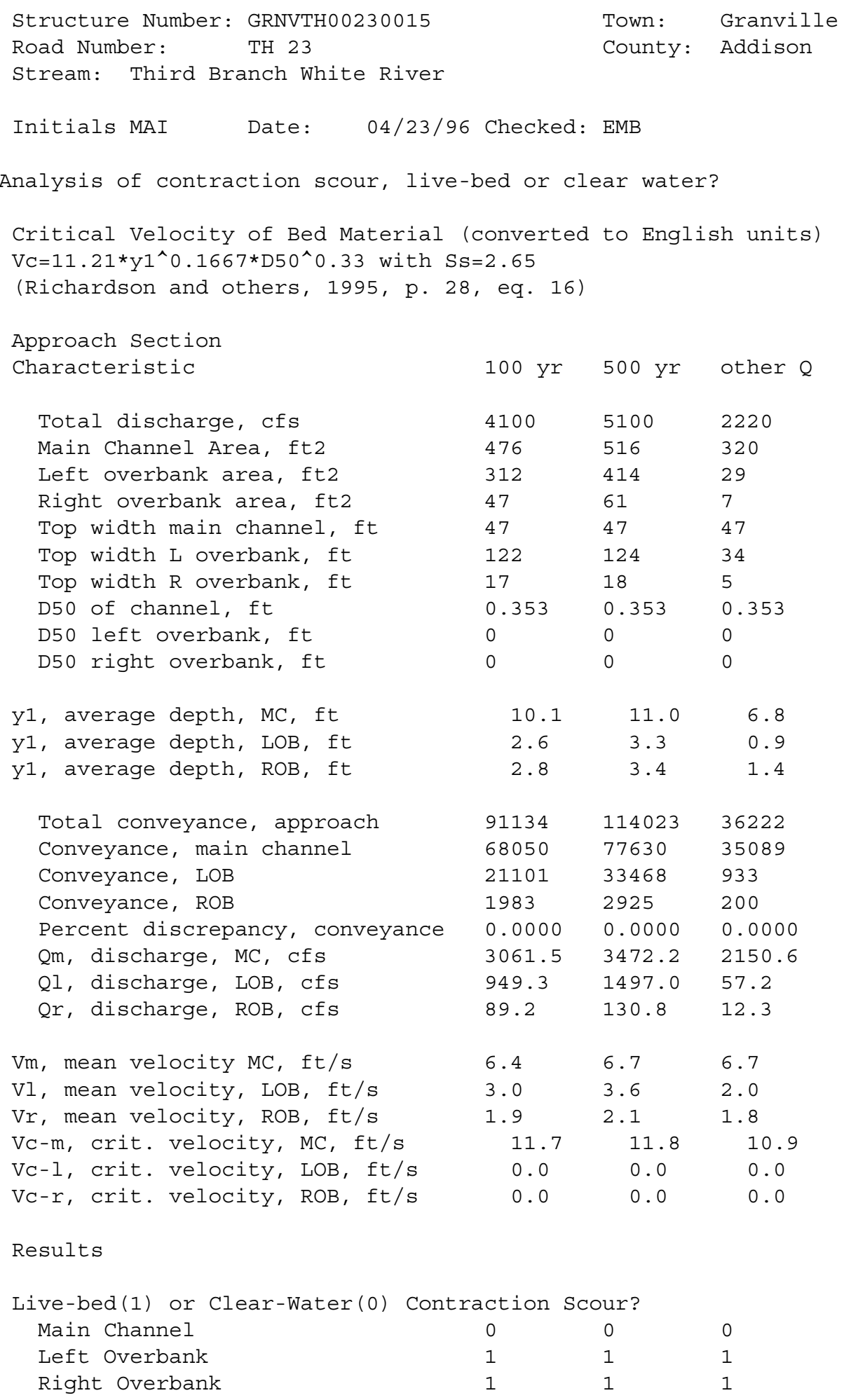


Clear water Contraction Scour in MAIN CHANNEL

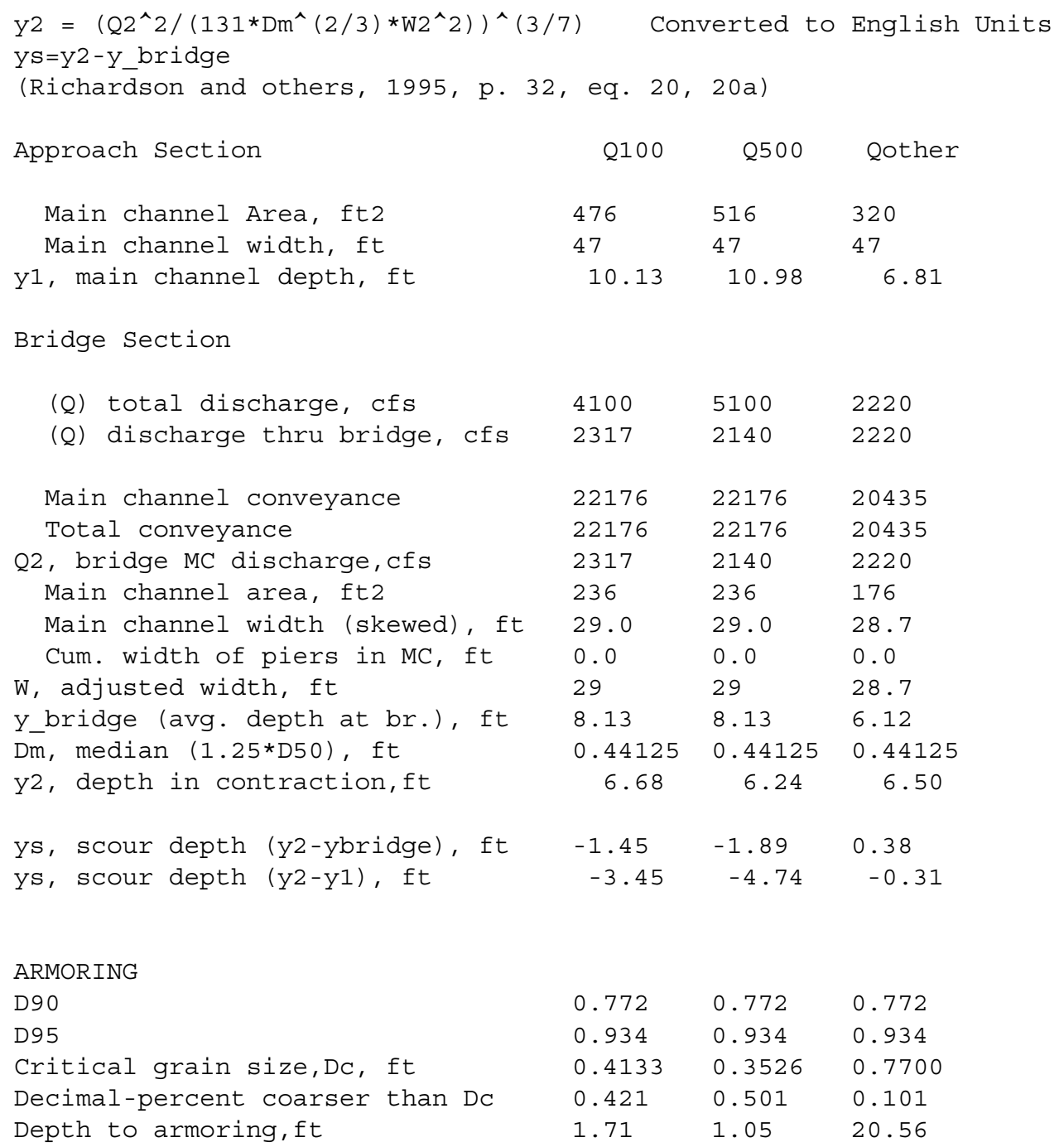


PRESSURE FLOW SCOUR COMPUTATION

\begin{tabular}{|c|c|c|c|}
\hline Structure Number: GRNVTH00230015 & & Town: & Granville \\
\hline Road Number: & & County: & Addison \\
\hline Third Branch Whit & River & & \\
\hline Initial: EMB $\quad$ Date: $10 / 10 / 96$ & Checked: & MAI & \\
\hline Pressure Flow Scour (contraction sce & bur for or & rifice flo & ow conditions) \\
\hline $\mathrm{Hb}+\mathrm{Ys}=\mathrm{Cq} * \mathrm{qb} r / \mathrm{Vc}$ & $C f=1$. & $.5 * \operatorname{Fr}^{\wedge} 0.43$ & $3(<=1)$ \\
\hline Chang Equation & $\mathrm{Hb} /(\mathrm{ya}-\mathrm{w})-$ & $-0.56)]+0$. & $.79 \quad(<=1)$ \\
\hline & Q100 & Q500 & OtherQ \\
\hline Q thru bridge main chan, cfs & 2317 & 2140 & 0 \\
\hline Vc, critical velocity, ft/s & 11.7 & 11.8 & 0 \\
\hline Vc, critical velocity, m/s & 3.565986 & 3.596464 & 0 \\
\hline Main channel width (skewed), ft & 28.6 & 28.6 & 0 \\
\hline Cum. width of piers, ft & 0 & 0 & 0 \\
\hline w, adjusted width, ft & 28.6 & 28.6 & 0 \\
\hline qbr, unit discharge, $f t^{\wedge} 2 / \mathrm{s}$ & 81.01399 & 74.82517 & ERR \\
\hline qbr, unit discharge, $\mathrm{m}^{\wedge} 2 / \mathrm{s}$ & 7.525711 & 6.950808 & $\mathrm{~N} / \mathrm{A}$ \\
\hline Area of full opening, $\mathrm{ft}^{\wedge} 2$ & 235.7 & 235.7 & 0 \\
\hline Hb, depth of full opening, ft & 8.241259 & 8.241259 & ERR \\
\hline Hb, depth of full opening, m & 2.511813 & 2.511813 & $\mathrm{~N} / \mathrm{A}$ \\
\hline Fr, Froude number MC & 0.61 & 0.56 & 1 \\
\hline Cf, Fr correction factor $(<=1.0)$ & 1 & 1 & 1.5 \\
\hline Elevation of Low Steel, ft & 497.15 & 497.15 & 0 \\
\hline Elevation of Bed, ft & 488.9087 & 488.9087 & $\mathrm{~N} / \mathrm{A}$ \\
\hline Elevation of approach WS, ft & 500.62 & 501.45 & 0 \\
\hline HF, bridge to approach, ft & 0.15 & 0.15 & 0 \\
\hline Elevation of WS immediately US, ft & 500.47 & 501.3 & 0 \\
\hline ya, depth immediately US, ft & 11.56126 & 12.39126 & $\mathrm{~N} / \mathrm{A}$ \\
\hline ya, depth immediately US, m & 3.592685 & 3.850609 & $\mathrm{~N} / \mathrm{A}$ \\
\hline Mean elev. of deck, ft & 498.54 & 498.54 & 0 \\
\hline$w$, depth of overflow, ft $(>=0)$ & 1.93 & 2.76 & 0 \\
\hline Cc, vert contrac correction $(<=1.0)$ & 0.961953 & 0.961953 & $\mathrm{ERR}$ \\
\hline Ys, depth of scour (chang), ft & -1.04312 & -1.64934 & $\mathrm{~N} / \mathrm{A}$ \\
\hline
\end{tabular}




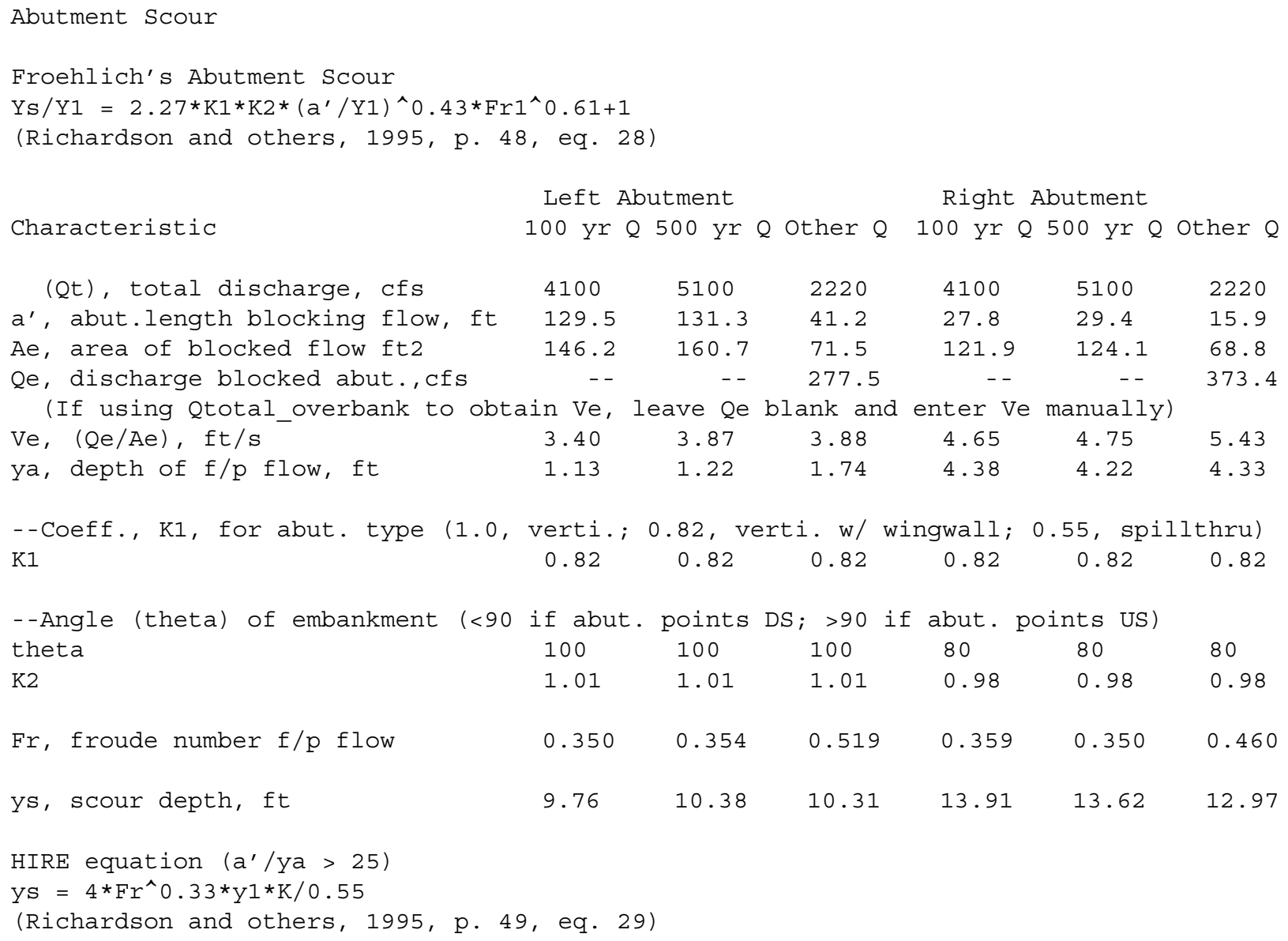




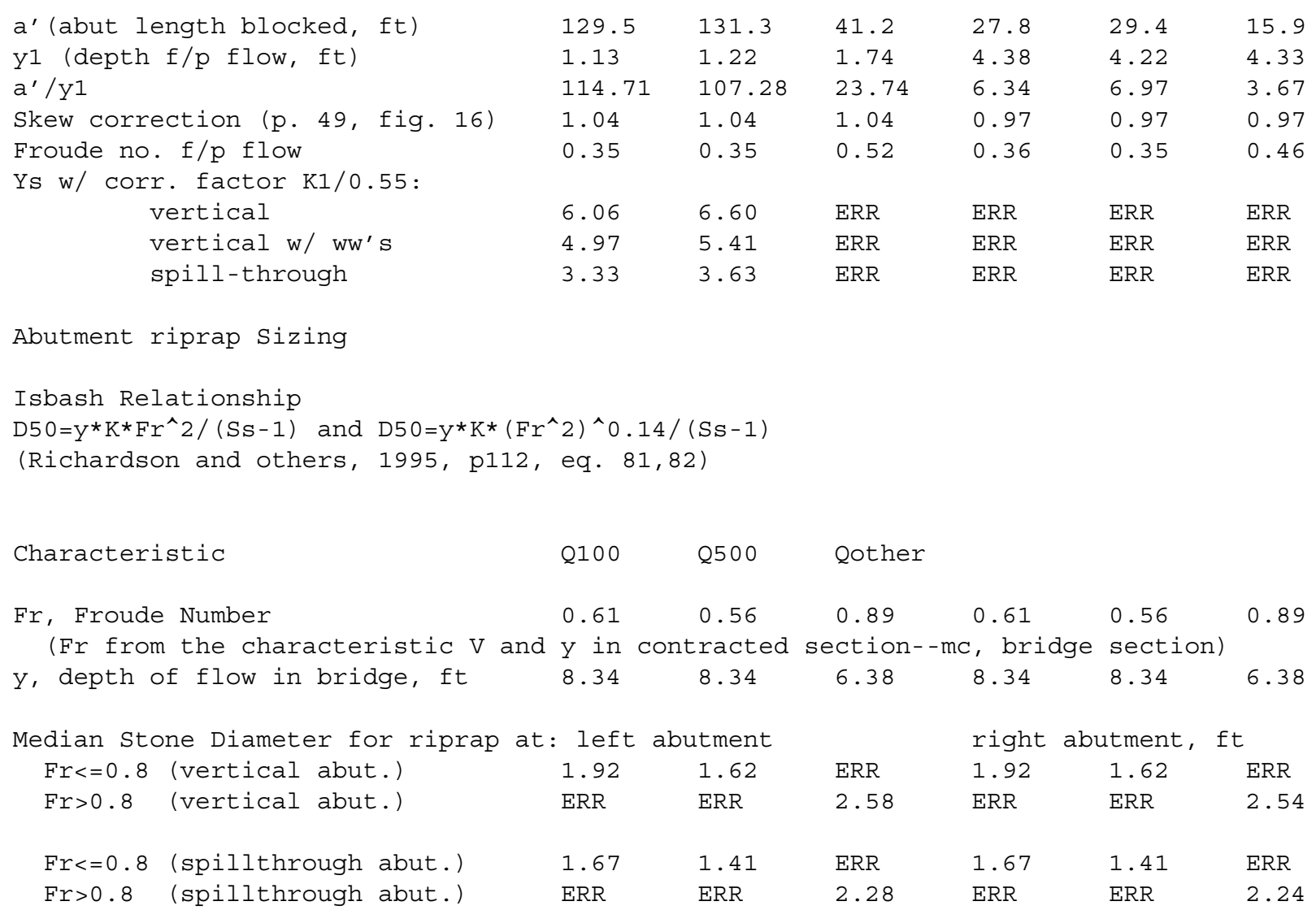

